\title{
Long-term particulate matter modeling for health effect studies in California - Part 1: Model performance on temporal and spatial variations
}

\author{
J. Hu ${ }^{1}$, H. Zhang ${ }^{1}$, Q. Ying ${ }^{2}$, S.-H. Chen ${ }^{3}$, F. Vandenberghe ${ }^{4}$, and M. J. Kleeman ${ }^{1}$ \\ ${ }^{1}$ Department of Civil and Environmental Engineering, University of California, Davis, One Shields Avenue, Davis, CA, USA \\ ${ }^{2}$ Zachry Department of Civil Engineering, Texas A\&M University, College Station, TX, USA \\ ${ }^{3}$ Department of Land, Air, and Water Resources, University of California, Davis, One Shields Avenue, Davis, CA, USA \\ ${ }^{4}$ Research Applications Laboratory, National Center for Atmospheric Research, Boulder, CO, USA
}

Correspondence to: M. J. Kleemann (mjkleeman@ucdavis.edu)

Received: 5 June 2014 - Published in Atmos. Chem. Phys. Discuss.: 14 August 2014

Revised: 10 February 2015 - Accepted: 4 March 2015 - Published: 30 March 2015

\begin{abstract}
For the first time, a decadal (9 years from 2000 to 2008) air quality model simulation with $4 \mathrm{~km}$ horizontal resolution over populated regions and daily time resolution has been conducted for California to provide air quality data for health effect studies. Model predictions are compared to measurements to evaluate the accuracy of the simulation with an emphasis on spatial and temporal variations that could be used in epidemiology studies. Better model performance is found at longer averaging times, suggesting that model results with averaging times $\geq 1$ month should be the first to be considered in epidemiological studies. The UCD/CIT model predicts spatial and temporal variations in the concentrations of $\mathrm{O}_{3}, \mathrm{PM}_{2.5}$, elemental carbon (EC), organic carbon (OC), nitrate, and ammonium that meet standard modeling performance criteria when compared to monthly-averaged measurements. Predicted sulfate concentrations do not meet target performance metrics due to missing sulfur sources in the emissions. Predicted seasonal and annual variations of $\mathrm{PM}_{2.5}$, EC, OC, nitrate, and ammonium have mean fractional biases that meet the model performance criteria in 95, 100, 71,73 , and $92 \%$ of the simulated months, respectively. The base data set provides an improvement for predicted population exposure to PM concentrations in California compared to exposures estimated by central site monitors operated 1 day out of every 3 days at a few urban locations.

Uncertainties in the model predictions arise from several issues. Incomplete understanding of secondary organic aerosol formation mechanisms leads to OC bias in the model
\end{abstract}

results in summertime but does not affect $\mathrm{OC}$ predictions in winter when concentrations are typically highest. The $\mathrm{CO}$ and NO (species dominated by mobile emissions) results reveal temporal and spatial uncertainties associated with the mobile emissions generated by the EMFAC 2007 model. The WRF model tends to overpredict wind speed during stagnation events, leading to underpredictions of high PM concentrations, usually in winter months. The WRF model also generally underpredicts relative humidity, resulting in less particulate nitrate formation, especially during winter months. These limitations must be recognized when using data in health studies. All model results included in the current manuscript can be downloaded free of charge at http: //faculty.engineering.ucdavis.edu/kleeman/.

\section{Introduction}

Numerous scientific studies have demonstrated associations between exposure to ambient airborne particulate matter (PM) and a variety of health effects, such as cardiovascular diseases (Dockery, 2001; Ford et al., 1998; Franchini and Mannucci, 2009; Langrish et al., 2012; Le Tertre et al., 2002), respiratory diseases (Gordian et al., 1996; Hacon et al., 2007; Sinclair and Tolsma, 2004; Willers et al., 2013), low birth weight and birth defects (Barnett et al., 2011; Bell et al., 2010; Brauer et al., 2008; Laurent et al., 2014, 2013; Stieb et al., 2012), lung cancer (Beelen et al., 2008; Beeson et al., 
1998; Pope et al., 2002; Vineis et al., 2006), mortality, and lower life expectancy (Chen et al., 2013; Correia et al., 2013; Dockery et al., 1993; Franklin et al., 2007; Goldgewicht, 2007; Cao et al., 2011; Laden et al., 2000; Ostro et al., 2006; Pope et al., 2009). Recently a few studies have investigated the associations between particle composition and health effects (Bell et al., 2010, 2007; Burnett et al., 2000; Cao et al., 2012; Franklin et al., 2008; Ito et al., 2011; Krall et al., 2013; Levy et al., 2012; Mar et al., 2000; Ostro et al., 2007, 2010; Son et al., 2012). However, there remains large uncertainty about which PM components are most responsible for the observed health effects, possibly due to the fact that central site monitoring measurements used in the PM composition studies have limited temporal, spatial, and chemical resolution, which could potentially lead to misclassification of exposure estimates and mask some detailed correlations. Central site PM measurements typically have a collection schedule of one sample every 3 or 6 days at a few sites used to represent an entire population region. Important particle size distribution and chemical composition information is not always routinely measured. Additional information relating PM composition to health effects would provide a solid foundation to design effective PM control strategies to protect public health at a reduced economic and social cost.

Chemical transport models (CTMs) have recently been used as one of the alternative approaches to address the limitations of central site monitors (Anenberg et al., 2010; Bravo et al., 2012; Sarnat et al., 2011; Tainio et al., 2013). The latest generation of CTMs represents a "state-of-the-science" understanding of emissions, transport, and atmospheric chemistry. CTM predictions provide more detailed composition information and full spatial coverage of air pollution impacts with a typical temporal resolution of $1 \mathrm{~h}$. CTMs have great potential to fill the time and space gaps in the central site monitoring data set for PM measurements, leading to improved exposure assessment in epidemiological studies.

The CTM applications in epidemiology studies to date have generally used relatively coarse spatial resolutions in order to reduce computational burden. Global CTMs have used horizontal resolutions of over $100 \mathrm{~km}$ and regional CTMs have used resolution of $12-36 \mathrm{~km}$. These resolutions cannot capture fine spatial gradients of PM concentrations, especially in areas with diverse topography and demography. Previous CTMs predictions used in epidemiology studies have also been limited to time periods less than 1 year. Recently Zhang et al. (2014a) evaluated the performance of the Community Multiscale Air Quality (CMAQ) model over a 7-year period in the eastern USA, but no other long-term CTMs studies for health effect analyses have been published to date. As a further limitation, previous epidemiology studies based on CTM predictions have mostly used predicted particles with aerodynamic diameter less than $2.5 \mu \mathrm{m}\left(\mathrm{PM}_{2.5}\right)$ mass concentrations without taking full advantage of the ability of CTMs to simultaneously estimate population exposure to multiple particle size fractions, chemical components, and source contributions. The variation in CTM prediction bias as a function of space and time due to uncertainties in model inputs (emissions, meteorological fields, mechanism parameters) is often not sufficiently characterized to understand potential impacts on health effect estimates. Detailed analyses are needed to assess the temporal and spatial features of CTM predictions to identify accurate and/or unbiased information for exposure assessment before such information can be applied in health effect studies (Beevers et al., 2013).

The objective of the current study is to develop and apply advanced source-oriented CTMs to predict the concentrations and sources for enhanced PM exposure assessment in epidemiological studies over a long-term period with high spatial resolution in California. California is chosen as the focus area for the current study because it has extensive infrastructure to support CTM studies, and it has one of the largest populations in the USA that is experiencing unhealthy levels of PM pollution. In 2013, 104 US counties with a population of 65 million people were in nonattainment with the National Ambient Air Quality Standards for $\mathrm{PM}_{2.5}$ (EPA, 2013). Approximately half of that population (31 million people) lives in 29 California counties, meaning that California suffers a disproportionately large share of US PM-related mortality (Fann et al., 2012). The California Air Resources Board (CARB) estimates that 14000-24 000 California residents die prematurely each year due to particulate air pollution (Tran, 2008). The severity of this problem has motivated extensive investments to support air pollution studies. California has the densest ambient PM measurement network, the most accurate emissions inventories, and the most health effect study groups of any state in the United States. Rich data sets are available to support model application and evaluation.

The current study is the first attempt to address the sparse PM data problem in exposure assessment using CTM results over a $\sim$ decadal time period (9 years from 2000 to 2008) over a domain spanning $\sim 1000 \mathrm{~km}$ at a spatial resolution of $4 \mathrm{~km}$. Companion studies have modeled primary $\mathrm{PM}_{2.5}$ and $\mathrm{PM}_{0.1}$ (particles with aerodynamic diameter less than $0.1 \mu \mathrm{m}$ ) concentrations and sources in California (Hu et al., $2014 a, b)$. The current paper, as the third in the series, focuses on model evaluation of total (= primary + secondary) $\mathrm{PM}_{2.5}$ and major components (elemental carbon (EC), organic carbon (OC), nitrate, sulfate, ammonium), emphasizing the aspects of temporal and spatial variations, to identify the features of the CTM results that could add skill to the exposure assessment for epidemiological studies. A future study will investigate the model capability for PM source apportionment of primary and secondary organic aerosols, which is currently an area with great uncertainty. 


\section{Methods}

\subsection{Air quality model description}

The host air quality model employed in the current study is based on the Eulerian source-oriented University of California, Davis/California Institute of Technology (UCD/CIT) chemical transport model (Chen et al., 2010; Held et al., 2004; Held et al., 2005; Hixson et al., 2010, 2012; Hu et al., 2012, 2010; Kleeman and Cass, 2001; Kleeman et al., 1997, 2007; Mahmud, 2010; Mysliwiec and Kleeman, 2002; Rasmussen et al., 2013; Ying et al., 2008; Ying et al., 2007; Ying and Kleeman, 2006; Zhang and Ying, 2010). The UCD/CIT model includes a complete description of atmospheric transport, deposition, chemical reaction, and gas-particle transfer. The details of the standard algorithms used in the UCD/CIT family of models have been described in the above references and therefore are not repeated here. Only the aspects that are updated during the current study are discussed in the following section.

The photochemical mechanism used by the UCD/CIT model was updated to reflect the latest information from smog-chamber experiments. The SAPRC-11 photochemical mechanism (Carter and Heo, 2012, 2013) was used to describe the gas-phase chemical reactions in the atmosphere. The secondary organic aerosol (SOA) treatment was updated following the method described in Carlton et al. (2010). Seven organic species (isoprene, monoterpenes, sesquiterpenes, long-chain alkanes, high-yield aromatics, low-yield aromatics, and benzene) are considered as precursors for SOA formation. A total of 12 semi-volatile and 7 nonvolatile products are formed from the oxidation of the precursor species. The gas-particle transfer of the semi-volatile and nonvolatile products in the UCD/CIT model is dynamically calculated based on the gas vapor pressures calculated over the particle surface and the kinetic limitations to mass transfer. The explicit chemical reactions and the parameters for the thermodynamic equilibrium calculation (i.e., enthalpy of vaporization, saturation concentrations, and stoichiometric yields) are provided in Carlton et al. (2010) and references therein.

Model simulations were configured using a one-way nesting technique with a parent domain of $24 \mathrm{~km}$ horizontal resolution that covered the entire state of California (referred to as CA_24 km) and two nested domains with $4 \mathrm{~km}$ horizontal resolution that covered the Southern California Air Basin (SoCAB)(referred to as SoCAB_4 km) and the San Francisco Bay Area, San Joaquin Valley (SJV), and South Sacramento Valley air basins (referred to as SJV_4 km) (shown in Fig. 1). The nested $4 \mathrm{~km}$ resolution domains are configured to cover the major ocean, coast, urban, and rural regions that influence California's air quality and, most importantly, to cover most of the California's population for the purpose of health effect analyses. Over $92 \%$ of California's population lives in the $4 \mathrm{~km}$ domains based on the most recent census information.

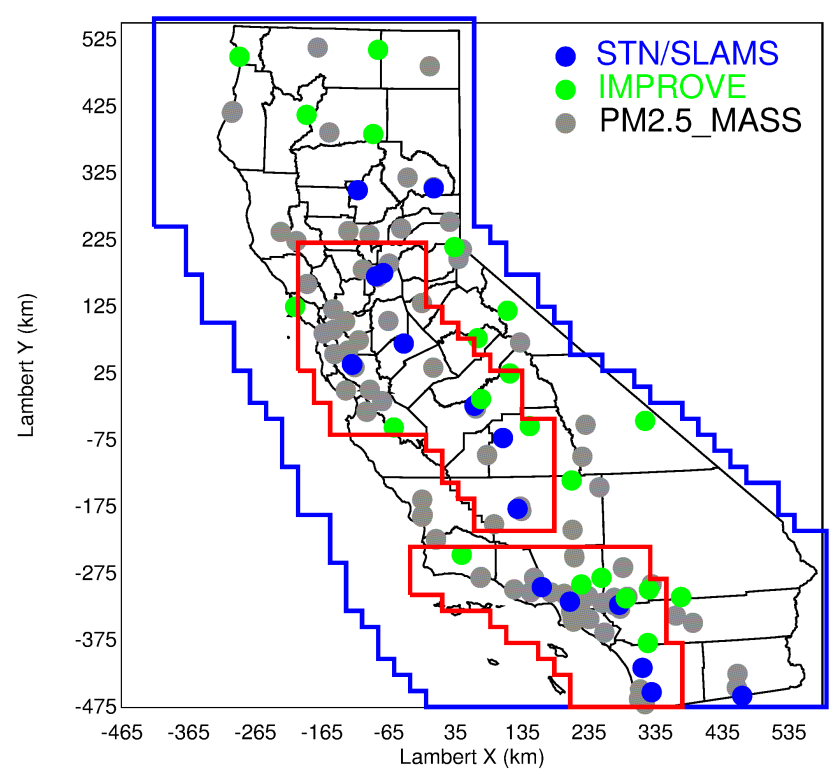

Figure 1. Modeling domains (blue lines outline the CA_24 km domain, and red lines outline the SoCAB_4 km (bottom) and SJV_4 km domains (top)) and PM measurement sites (dots). Blue dots represent the sites of the $\mathrm{PM}_{2.5}$ Speciation Trends Network (STN) and the state and local air monitoring Stations (SLAMS), green dots represent the Interagency Monitoring of Protected Visual Environments (IMPROVE) sites; gray dots represent the $\mathrm{PM}_{2.5}$ federal reference method (FRM) sites.

The UCD/CIT model was configured with 16 vertical layers up to a height of $5 \mathrm{~km}$ above ground level in all the mother and nested domains, with 10 layers in the first $1 \mathrm{~km}$. Note that the use of relatively shallow vertical domains is only appropriate in regions with well-defined air basins and would not be appropriate for locations in the eastern USA or other regions with moderate topography. Particulate composition, number and mass concentrations are represented in 15 size bins, ranging from 0.01 to $10 \mu \mathrm{m}$ in diameter. Primary particles are assumed to be internally mixed, i.e., all particles within a size bin have the same composition. Previous studies (Ying et al., 2007) have shown that this assumptions provides adequate predictions for total PM concentrations relative to source-oriented mixing treatments in California when feedbacks to meteorology are not considered (Zhang et al., 2014b).

\subsection{Meteorology and emissions}

Hourly meteorology inputs (wind, temperature, humidity, precipitation, radiation, air density, and mixing layer height) were generated using the Weather Research and Forecasting (WRF) model v3.1.1 Wang et al., 2010; Shamarock et al., 2008). Two-way nesting was used with the outer domain at $12 \mathrm{~km}$ resolution and the inner nested domain at $4 \mathrm{~km}$ resolution. North American Regional Reanalysis data 
with $32 \mathrm{~km}$ resolution and $3 \mathrm{~h}$ time resolution were used as initial and boundary conditions of the coarse $12 \mathrm{~km}$ domain. The WRF model was configured with 31 vertical layers up to $100 \mathrm{hPa}$ (around $16 \mathrm{~km}$ ). Four-dimensional data assimilation was used. The Yonsei University (YSU) boundary layer scheme, thermal diffusion land-surface scheme, and Monin-Obukhov surface layer scheme were used based on results from a previous study in California (Mahmud, 2010; Zhao et al., 2011). The surface wind was overpredicted with the original version of WRF, especially for wind speed less than $3 \mathrm{~m} \mathrm{~s}^{-1}$, consistent with other studies in California (Angevine et al., 2012; Fast et al., 2014; Michelson et al., 2010a). Overprediction of the slow winds caused underprediction of concentrations during high pollution events. A recent study (C.F., Mass, personal communication, 2010) found that increasing the surface friction velocity $\left(u^{*}\right)$ by $50 \%$ reduced the bias in surface wind predictions in a complex-terrain domain. This technique was tested and adopted in previous studies (Hu et al., 2012, 2014a; Mass and Ovens, 2010; Wang et al., 2015) where it improved the accuracy of air quality predictions. In the current study, a 1-year sensitivity simulation for California in the year 2000 revealed that increasing $u^{*}$ by $50 \%$ improved the mean wind bias from 1.15 to $-0.50 \mathrm{~m} \mathrm{~s}^{-1}$ and lowered the root-mean-square error (RMSE) from 2.95 to $2.20 \mathrm{~m} \mathrm{~s}^{-1}$ (Hu et al., 2014a). It should be noted that this approach reduces positive bias for wind speeds less than $\sim 3 \mathrm{~m} \mathrm{~s}^{-1}$ but increases negative bias at higher speeds. Analysis of the wind speed measurements in California air basins shows that $78 \%$ of winds are less than $3 \mathrm{~m} \mathrm{~s}^{-1}$. Therefore, increasing $u^{*}$ by $50 \%$ in our study improves the wind predictions for a majority of cases during the modeling period. Similar detailed evaluations should be conducted before applying the increased $u^{*}$ approach to other regions and periods. It should also be noted that concentration is inversely proportional to wind speed. As a result, the concentration bias created by a wind speed bias of $1 \mathrm{~m} \mathrm{~s}^{-1}$ at a true wind speed of $3.5 \mathrm{~m} \mathrm{~s}^{-1}$ is 50 times lower than the concentration bias created by the same wind speed bias at a true wind speed of $0.5 \mathrm{~m} \mathrm{~s}^{-1}$. This implies that the underprediction of high wind speeds in the present study has minimal impact on concentration fields used for epidemiology.

Hourly average meteorology outputs at the air-qualitymodel vertical layer heights were created by averaging the WRF fields. The meteorology predictions were evaluated against meteorological observations (CARB, 2011a). The meteorological statistical evaluation over the period 20002006 has been presented in a previous study ( $\mathrm{Hu}$ et al., 2014a), and the results in the period 2007-2008 are consistent with those years. In summary, meteorology predictions of temperature and wind speed generally meet benchmarks suggested by Emery et al. (2001). Mean fractional biases (MFBs) of temperature and wind are generally within \pm 0.15 , RMSEs of temperature are around $4^{\circ} \mathrm{C}$, and RMSEs of wind are generally lower than $2.0 \mathrm{~m} \mathrm{~s}^{-1}$, especially in the SoCAB and SJV air basins which are the focus of the current study. Relative humidity is underpredicted, consistent with findings in other studies in California (Bao, 2008; Michelson et al., 2010b). Precipitation is also underpredicted with a MFB of $-76.1 \%$ and RMSE of $2.84 \mathrm{~mm} \mathrm{~h}^{-1}$. Wind, temperature, and humidity are the major meteorological factors that influence the PM concentrations. Further discussions of the uncertainties in meteorology predictions on PM predictions are included in the Results section.

Hourly gridded gas and particulate emissions were generated using an updated version of the emissions model described by Kleeman and Cass (1998). The standard emissions inventories from anthropogenic sources (i.e., point sources, stationary area sources, and mobile sources) were provided by CARB. Size- and composition-resolved particle emissions were specified using a library of primary particle source profiles measured during actual source tests (Cooper, 1989; Harley et al., 1992; Hildemann et al., 1991a, b; Houck, 1989; Kleeman et al., 2008, 1999, 2000; Robert et al., 2007a, b; Schauer et al., 1999a, b, 2001, 2002a, b; Taback et al., 1979). A few studies have revealed some uncertainties associated with the standard emissions inventories. Millstein and Harley (2009) found that PM and $\mathrm{NO}_{\mathrm{x}}$ emissions from diesel-powered construction equipment were over-estimated by a factor of 3.1 and 4.5 , respectively. Countess (2003) suggested that a scaling factor of $0.33-0.74$ should be applied to the fugitive dust emissions in the Californian San Joaquin Valley. Therefore, scaling factors of 0.32 for off-road diesel sources and 0.50 for dust emissions were applied in the current study. The EMFAC 2007 model (CARB, 2008) was used to scale the mobile emissions using predicted temperature and relative humidity fields through the entire 9-year modeling episode. Biogenic emissions were generated using the Biogenic Emissions Inventory System v3.14 (BEIS3.14), which includes a $1 \mathrm{~km}$ resolution land cover database with 230 different vegetation types (Vukovich and Pierce, 2002). Sea-salt emissions were generated online based on the formulation described by de Leeuw et al. (2000) for the surf zone and the formulation described by Gong (2003) for the open ocean. Emissions from wildfires and open burning at $1 \mathrm{~km} \times 1 \mathrm{~km}$ resolution were obtained from the Fire INventory from NCAR (FINN) (Hodzic et al., 2007; Wiedinmyer et al., 2011). The FINN inventory provides SAPRC99 speciated daily emissions of gaseous and particulate emissions (EC, organic matter (OM), $\mathrm{PM}_{2.5}$, and $\mathrm{PM}_{10}$ ) based on satellite observations of open burning events. Each open burning event is allocated to model grid cells of each domain based on the reported longitude/latitude of the event and the area burned. The emissions were injected at the height of the atmospheric mixing layer (PBL). The temporal variation of wildfire emissions was obtained from the Western Regional Air Partnership report (WRAP, 2005). A size distribution profile was calculated based on assumptions described in Hodzic et al. (2007). 


\subsection{Ambient air quality measurements}

The evaluation data set was compiled from several measurement networks, including CARB's "2011 Air Quality Data DVD" (CARB, 2011b) and the database maintained by the Interagency Monitoring of Protected Visual Environments (IMPROVE). The data DVD includes daily average mass concentrations of $\mathrm{PM}_{2.5}, \mathrm{EC}, \mathrm{OC}$, nitrate, sulfate, ammonium, and trace metals every 3 or 6 days at the sites of the $\mathrm{PM}_{2.5}$ Speciation Trends Network (STN) and the state and local air monitoring stations. There are a total 13 $\mathrm{PM}_{2.5}$ speciation sites included in the DVD covered in the $4 \mathrm{~km}$ domains during the modeling periods. The precision of STN measurements is estimated to be 3.5, 8.6, and 3.9\% for sulfate, nitrate, and ammonium, respectively (Sickles Ii and Shadwick, 2002). Measured EC concentrations at five sites are found to be exactly $0.5 \mu \mathrm{g} \mathrm{m}^{-3}$ on $>80 \%$ of the measurement days, suggesting corrupt or missing data at these locations. Therefore, these five sites were excluded in the evaluation for EC but still included in the evaluation for other PM components. The OC data were not blank corrected, resulting in a positive artifact by the NIOSH5040 method that is equivalent to approximately $1 \mu \mathrm{g} \mathrm{m}^{-3}$. Measured OC concentrations were blank corrected in the current study by subtracting $1 \mu \mathrm{g} \mathrm{m}^{-3}$ from all OC measurements. The IMPROVE network provides daily average mass concentrations every 3 days for $\mathrm{PM}_{2.5}, \mathrm{EC}, \mathrm{OC}$, nitrate, sulfate, and soil. There are a total of nine IMPROVE sites covered in the $4 \mathrm{~km}$ domains. The precision of IMPROVE measurements is estimated to be $4-6 \%$ for $\mathrm{PM}_{2.5}$ mass, nitrate, and sulfate and to be $>15 \%$ for EC and OC (http: //vista.cira.colostate.edu/improve/Publications/OtherDocs/ IMPROVEDataGuide/IMPROVEDataGuide.htm).

Daily average $\mathrm{PM}_{10}$ mass measurements and hourly measurements of several key gaseous pollutants (ozone, $\mathrm{CO}$, $\mathrm{NO}, \mathrm{NO}_{2}$, and $\mathrm{SO}_{2}$ ) are also included in the data DVD. There are a total of $66 \mathrm{PM}_{2.5}$ federal reference method (FRM) sites covered in the $4 \mathrm{~km}$ domains. Frank (2006) found that FRM $\mathrm{PM}_{2.5}$ mass measured using STN monitors was within $\pm 30 \%$ of reconstructed fine mass concentrations measured using IMPROVE monitors.

\section{Results and discussion}

\subsection{Statistical evaluation}

Statistical measures of MFB and mean fractional error (MFE) were calculated to evaluate the accuracy of model estimates in space and time. Boylan and Russell (2006) proposed concentration-dependent MFB and MFE performance goals and criteria, realizing that lower concentrations are more difficult to accurately predict. The performance goals are the level of accuracy close to the best that a model can be expected to achieve, while performance criteria are the level of accuracy acceptable for standard modeling applications.

Figures 2 and 3 show the monthly MFB and MFE values, respectively, of predicted daily average EC, OC, nitrate, ammonium, sulfate, and total $\mathrm{PM}_{2.5}$ mass in the $4 \mathrm{~km}$ domains. Measured EC, OC, nitrate, ammonium, and total $\mathrm{PM}_{2.5}$ mass concentrations follow similar seasonal patterns with high concentrations occurring in winters (indicated by blue colors in figures) and low concentrations occurring in summers (indicated by red colors in figures). These patterns are driven by the meteorological cycles (i.e., lower mixing layer and wind speed providing less dilution and lower temperature encouraging partitioning of ammonium nitrate to the particle phase) and the emissions variations (i.e., additional wood burning emissions for home heating in winters). The opposite seasonal variations in sulfate concentrations are observed due to higher oxidation rates from $\mathrm{S}(\mathrm{IV})$ to $\mathrm{S}(\mathrm{VI})$ and higher sulfur emissions from natural sources in summer (Bates et al., 1992).

EC predictions are in excellent agreement with measurements. MFBs in all months and MFEs in 107 months out of the total 108 months are within the model performance goal. EC MFBs and MFEs show no significant difference among months/seasons, indicating consistently good EC performance during the entire 9-year modeling period. OC, nitrate, sulfate, and ammonium, the PM components that include the secondary formation pathways, meet the MFBs model performance criteria in $71,73,46$, and $92 \%$ of the simulated months, respectively. These components generally have good agreement between predictions and measurements in winter months, with only a few months not meeting the performance criteria. When analyzing by season, predicted concentrations of these species are found to be more biased in summer months, especially for sulfate and nitrate. Different factors influence the seasonal profile of each species. The more significant OC underprediction in summertime is mainly associated with the underprediction of SOA due to incomplete knowledge of SOA formation mechanism at the present time. Similar patterns have been reported in other modeling studies outside California (Matsui et al., 2009; Volkamer et al., 2006; Zhang et al., 2014a; Zhang and Ying, 2011). Measured nitrate concentrations in summertime (1$5 \mu \mathrm{g} \mathrm{m}^{-3}$ ) are factors of 2-5 lower than concentrations in wintertime $\left(5-12 \mu \mathrm{g} \mathrm{m}^{-3}\right)$. Model predictions tend to underestimate the low particle phase nitrate concentrations in summer, especially when temperatures exceed $25^{\circ} \mathrm{C}$. Model predictions for particulate nitrate are usually less than $1 \mu \mathrm{g} \mathrm{m}^{-3}$ under these conditions, while $2-3 \mu \mathrm{g} \mathrm{m}^{-3}$ nitrate concentrations

are still observed in the ambient air. Similar underpredictions of summertime nitrate have been reported in other regional modeling studies (Appel et al., 2008; Tesche et al., 2006; Yu et al., 2005; Zhang et al., 2014a). Model calculations reflect thermodynamics and kinetic gas-particle transfer for ammonium nitrate in mixed particles, suggesting that 

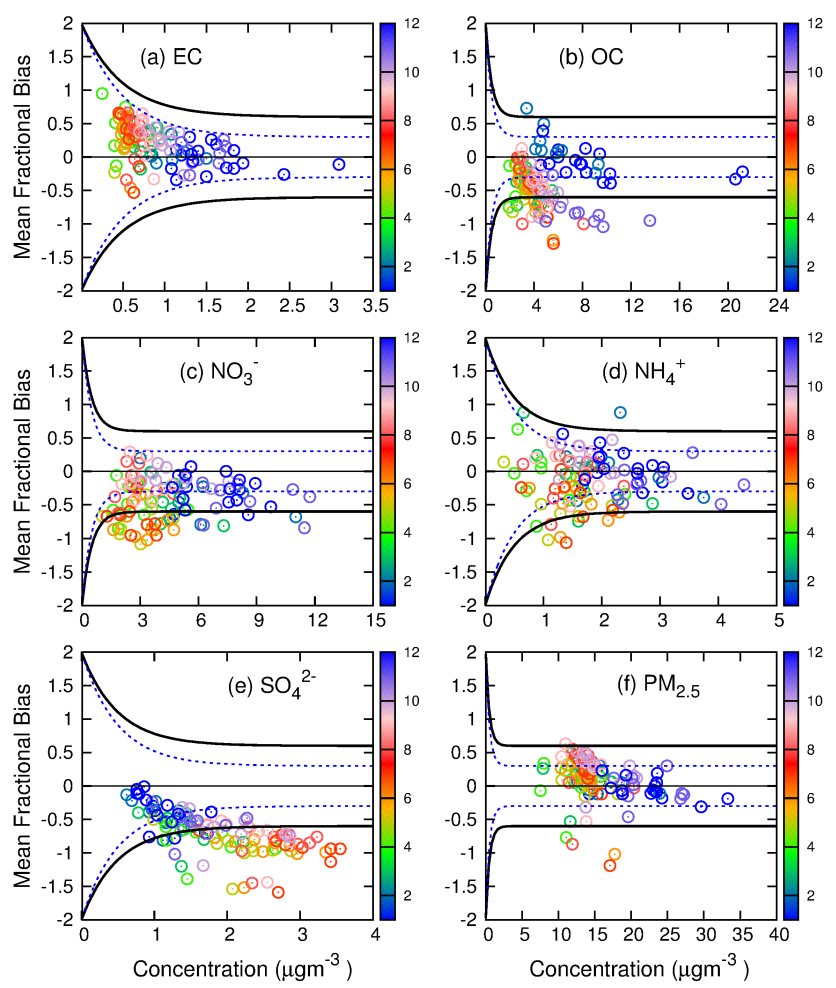

Figure 2. Monthly mean fractional bias (MFB) of $\mathrm{PM}_{2.5} \mathrm{EC}, \mathrm{OC}$, nitrate, ammonium, sulfate, and total mass. Solid lines represent the MFB criteria, and the blue dash lines represent the MFB goals.

some other form of nitrate is present in the real atmosphere, such as organo-nitrates (Day et al., 2010). Sulfate concentrations are consistently underpredicted throughout the modeling period at all locations, especially in Southern California where the measured sulfate concentrations are highest. Underprediction of sulfate has also been reported by other regional modeling studies in California (Chen et al., 2014; Fast et al., 2014) using different air quality models (e.g., CMAQ, WRF-Chem). This consistent behavior suggests that the specific model is not the cause of the sulfate underprediction. A global model study that included ocean dimethyl sulfide (DMS) emissions showed a better sulfate performance in California (Walker et al., 2012). Therefore, missing emissions sources such as the sulfur emitted as DMS from the Pacific Ocean likely contribute to the sulfate underpredictions in the current study. The sulfate concentrations at the sites in Southern California are $\sim 2$ to 3 times higher than in Northern California and are underpredicted by an even larger amount (with MFBs around -1.0). It is therefore likely that anthropogenic sulfur sources are missing in Southern California in addition to background DMS sources. In the remote areas where the sulfate concentrations are low, the omission of nucleation processes in the current study could reduce seed aerosol surface area onto which sulfuric acid can condense. This factor could contribute to the underpredic-
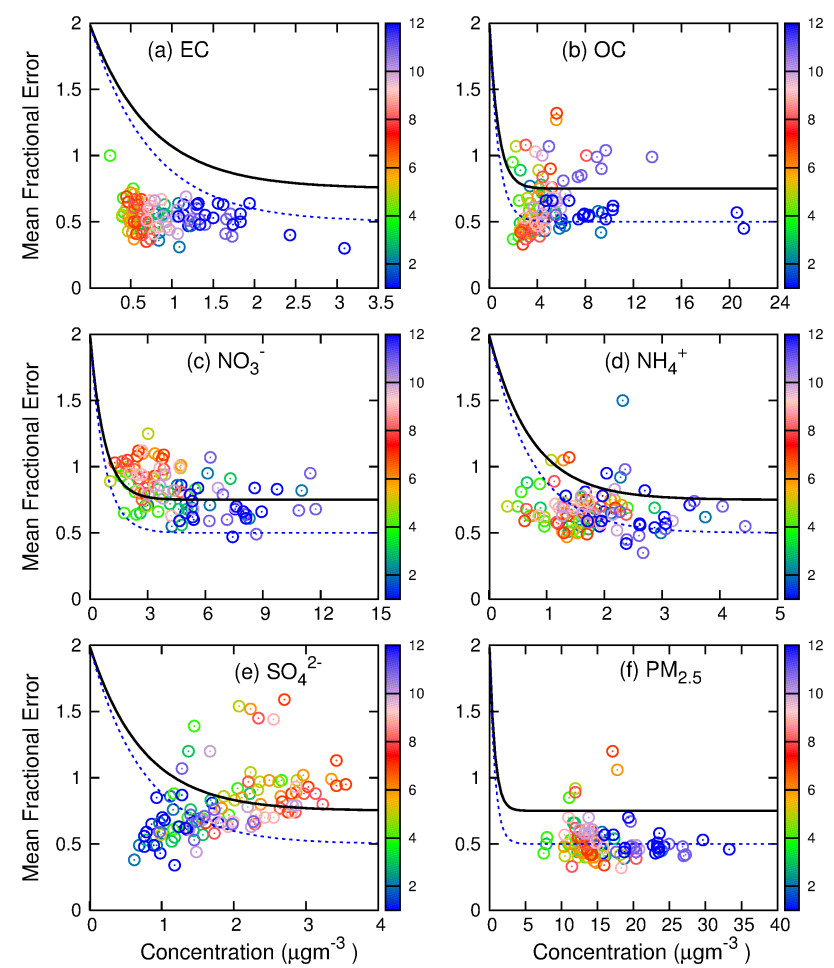

Figure 3. Monthly mean fractional errors (MFE) of $\mathrm{PM}_{2.5} \mathrm{EC}, \mathrm{OC}$, nitrate, ammonium, sulfate, and total mass. Solid lines represent the MFE criteria, and the blue dash lines represent the MFE goals.

tion of sulfate mass in these regions along with the missing sulfur sources. Ammonium is drawn to acidic particles and so ammonium concentration predictions reflect the combined trends of nitrate and sulfate predictions.

The model predictions of total $\mathrm{PM}_{2.5}$ mass, as a summation of all components, show very good agreement with measurements, with only 3 summer months and 2 spring months ( $5 \%$ of all simulated months) not meeting the performance criteria, and 78 and $75 \%$ of months within the performance goals for MFB and MFE, respectively. The largest biases in the total $\mathrm{PM}_{2.5}$ mass occur in summer. Underprediction in summer sulfate and $\mathrm{OC}$ contribute to negative biases in the total $\mathrm{PM}_{2.5}$ mass predictions. Sulfate and OC concentrations in summer accounted for $\sim 18$ and $\sim 37 \%$ of the total $\mathrm{PM}_{2.5}$ mass. Sulfate and OC underprediction contributed to a combined $\sim 37 \%$ underprediction of total $\mathrm{PM}_{2.5}$ mass. However, positive biases in predicted dust concentrations rich in crustal elements such as aluminum and silica (Hu et al., 2014a) compensate for the underpredictions in carbonaceous components and water-soluble ions described above.

Figure 4 shows the MFB and MFE values of particulate species of $\mathrm{PM}_{2.5}$ total mass, EC, OC, nitrate, sulfate, ammonium and gaseous species of $\mathrm{O}_{3}, \mathrm{CO}, \mathrm{NO}, \mathrm{NO}_{2}$, and $\mathrm{SO}_{2}$ using daily averages across all measurement sites during the entire modeled 9-year period. $\mathrm{PM}_{2.5}$ total mass, EC, $\mathrm{OC}$, ammonium, and gaseous species of $\mathrm{O}_{3}, \mathrm{CO}$, and $\mathrm{NO}_{2}$ 

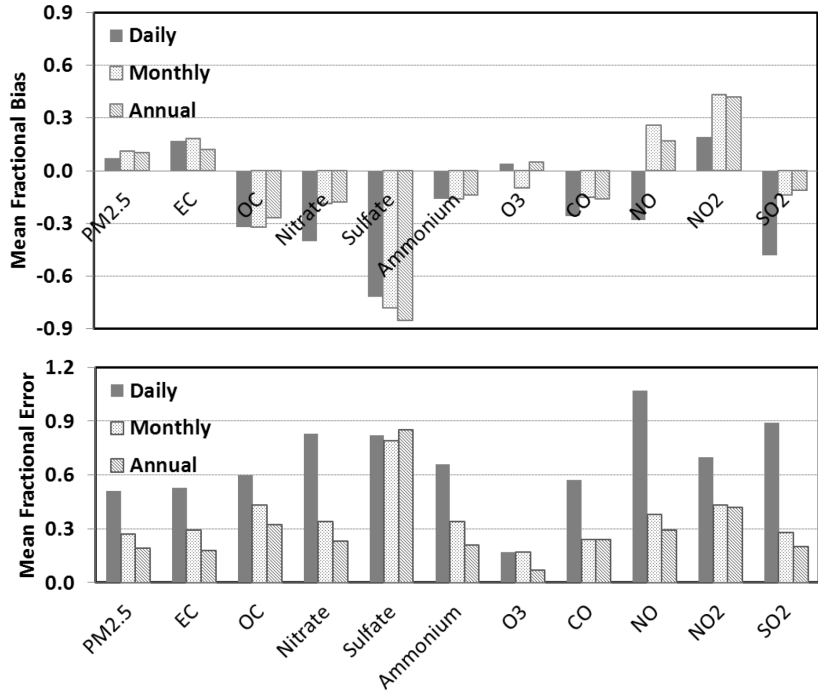

Figure 4. Mean fractional bias and mean fractional errors of PM and gaseous species when calculated using daily, monthly, and annual averages.

have MFBs within \pm 0.3 and MFE less than 0.75 , indicating general agreement between predictions and measurement for these species. Nitrate and NO have MFBs of -0.4 and -0.28 , respectively, but MFEs of 0.8 and 1.07 , respectively. The relatively moderate or small bias combined with relatively large error indicates that the daily predictions miss the extremely high and low concentrations. Sulfate and $\mathrm{SO}_{2}$ have high MFBs of -0.7 and -0.5 , respectively, and high MFEs of 0.8 and 0.9 , respectively, indicating that these species are consistently underpredicted.

Concentrations averaged over longer times, such as 1 month or 1 year, are used in some studies of air pollution health effects. A previous examination of primary particles in California revealed that air quality model predictions are more accurate over longer averaging time because the influence of extreme events and short-term variability is reduced as the averaging period gets longer ( $\mathrm{Hu}$ et al., 2014a). Figure 4 compares the MFB and MFE values for total (= primary + secondary) particulate matter and gaseous species using daily, monthly, and annual averages across all sites in the $4 \mathrm{~km}$ domains. The results demonstrate that longer averaging times produce better agreement between model predictions and measurements (except for sulfate, which is underpredicted due to missing emissions), because they remove the effects of random measurement errors at monitoring stations and variations in actual emissions rates that are not reflected in seasonally averaged emissions inventories. The reduced errors associated with longer averaging times indicate that model results may be most useful in epidemiological studies that can take advantage of averaging times $\geq 1$ month.

\subsection{Spatial and temporal variations}

Figure 5a shows the predicted and measured monthly average concentrations of $1 \mathrm{~h}$ peak $\mathrm{O}_{3}$ at five major urban sites (Sacramento, Fresno, Bakersfield, Los Angeles, and Riverside). Strong seasonal variations are observed in measured and predicted $1 \mathrm{~h}$ peak $\mathrm{O}_{3}$. The measured $1 \mathrm{~h}$ peak $\mathrm{O}_{3}$ shows seasonal variation from $100 \mathrm{ppb}$ in summertime to $20 \mathrm{ppb}$ in wintertime. The predicted high $1 \mathrm{~h}$ peak $\mathrm{O}_{3}$ concentrations in non-winter months are in good agreement with, or slightly higher than, ambient measured concentrations at all sites. This is consistent with studies in the eastern USA (Zhang et al., 2014a) which found similar slight overpredictions of summer $\mathrm{O}_{3}$ concentrations. Predicted $1 \mathrm{~h}$ peak $\mathrm{O}_{3}$ concentrations in cold winter months, however, are generally higher than measured values. Photochemical reaction rates in winter months are slow and the predicted $\mathrm{O}_{3}$ concentration at the surface mostly reflects downward mixing of the aloft background $\mathrm{O}_{3}$, followed by titration by surface $\mathrm{NO}$ emissions. The STN measurement sites in California are located in urban areas that are close to major freeways (see the site locations and nearby sources information in $\mathrm{Hu}$ et al., 2014a). The $4 \mathrm{~km} \times 4 \mathrm{~km}$ model grid cells that contain both freeways and monitors dilute the high NO concentrations around the measurement sites, leading to an underprediction of $\mathrm{O}_{3}$ titration and an overprediction of $\mathrm{O}_{3}$ concentrations. EPA recommends a threshold $\mathrm{O}_{3}$ value of $60 \mathrm{ppb}$ for model $\mathrm{O}_{3}$ evaluations (U.S. EPA, 2007), which means that wintertime $\mathrm{O}_{3}$ concentrations at the urban sites will generally not be considered in the formal model evaluation.

Figure $5 \mathrm{~b}$ and $\mathrm{c}$ show the predicted and measured monthly average $\mathrm{CO}$ and $\mathrm{NO}$ concentrations. Strong seasonal variations in $\mathrm{CO}$ and $\mathrm{NO}$ can be observed, with wintertime concentrations that are a factor of 3-5 higher than summertime concentrations. Model predictions generally reproduce the seasonal variations except at the Riverside site, where predicted seasonal variations are weaker than measurements. The model performance varies by simulation year and location. At the Sacramento and Fresno sties, predicted CO is in good agreement with measured concentrations in all months of 2002 through 2006, but CO is underpredicted in winter months of 2000-2001 and slightly overpredicted in most months of 2007-2008. At the Bakersfield site, CO is underpredicted in 2000-2003 and in good agreement with measurements in 2004-2005 (after which further measurements are not available). At the Los Angeles site, $\mathrm{CO}$ is in good agreement in 2000-2003 and overpredicted in the later years. At the Riverside site, $\mathrm{CO}$ is underpredicted in all months of 2000-2003, underpredicted in non-summer months in 20042006 , and in general agreement with measurements in 2007 2008. NO predictions generally agree well with measured NO concentrations in 2000-2004 at Sacramento, Fresno, Bakersfield, and Los Angeles and then are overpredicted in the later years. NO at Riverside is underpredicted in the winter months of 2000-2003 and overpredicted in the summer 

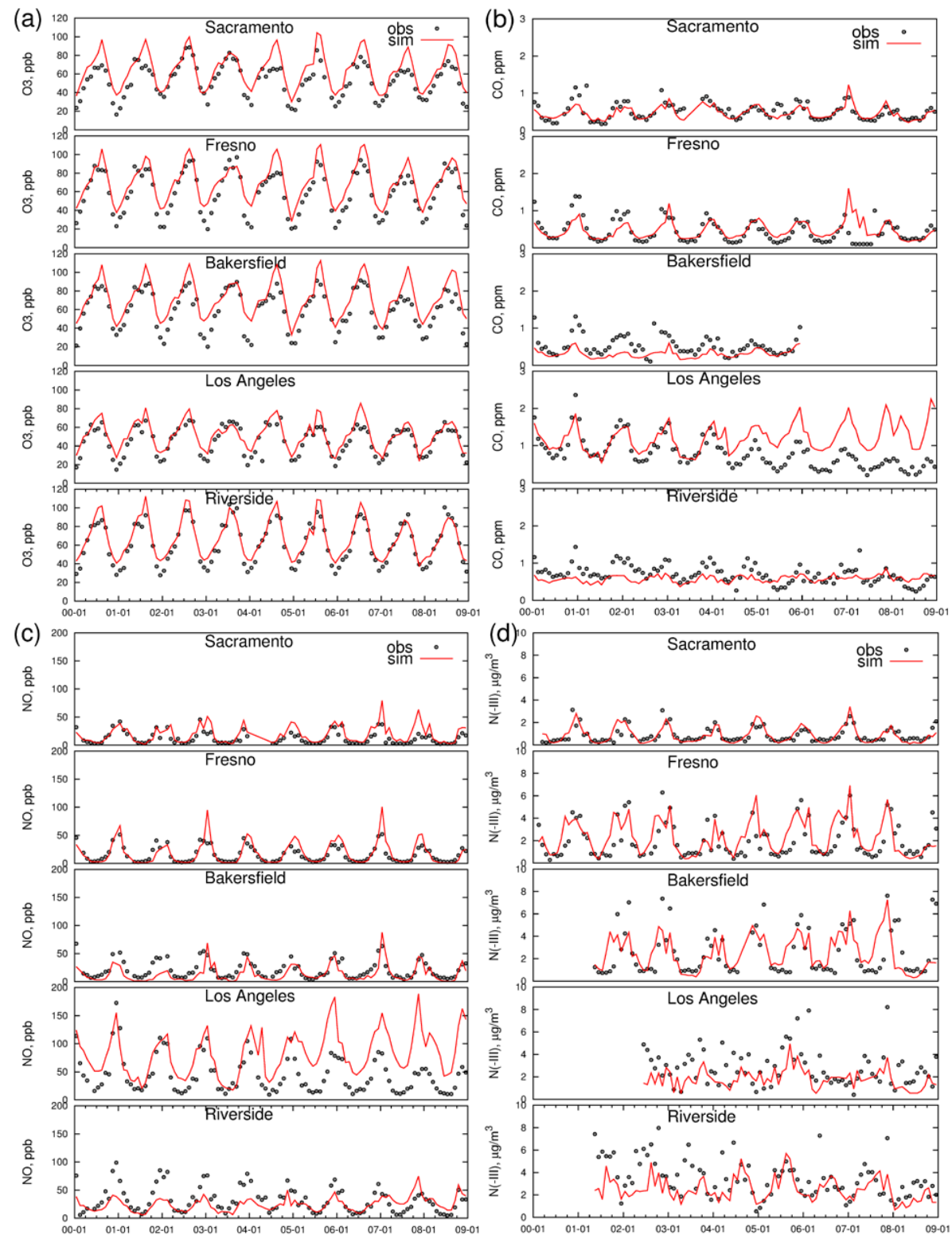

Figure 5. Predicted (red lines) vs. observed (dark dots) monthly average $\mathrm{O}_{3}$ (a), $\mathrm{CO}$ (b), $\mathrm{NO}$ (c), and $\mathrm{PM}_{2.5}$ ammonium (d) at Sacramento, Fresno, Bakersfield, Los Angeles, and Riverside.

months of 2004-2008. Mobile emissions are the dominant sources of $\mathrm{CO}$ and $\mathrm{NO}$ in California, contributing $>80 \%$ of total anthropogenic emissions (CARB, 2012). The results of the current modeling study suggest that uncertainties in the mobile emissions exist both in time and space.

A clear and similar decreasing trend is apparent in measured CO and NO concentrations from 2000 to 2008. This interannual trend is not well captured by the model predictions due to the uncertainties in the emissions. An adjusted NO prediction (NO_adj) can be calculated using $\mathrm{CO}$ as a tracer for the mobile emissions and dilution according to the equation

NO_adj $=$ NO_noadj $\times$ CO_predicted $/ C O \_m e a s u r e d$,

where NO_noadj is the NO predictions before the adjustment (i.e., the concentrations showing in Figure 5c). NO_adj has a higher correlation coefficient $\left(\mathrm{R}^{2}\right)$ with measured NO concentrations than the NO_noadj prediction at all the five monitoring sites (as shown in Fig. 7), and NO_adj has a regression slope closer to 1.0 than NO_noadj at three out of five sites. This suggests that either emissions or physical dilution processes in the model contribute to the errors observed in Fig. 5 (in addition to the possibility of errors in model chem- 

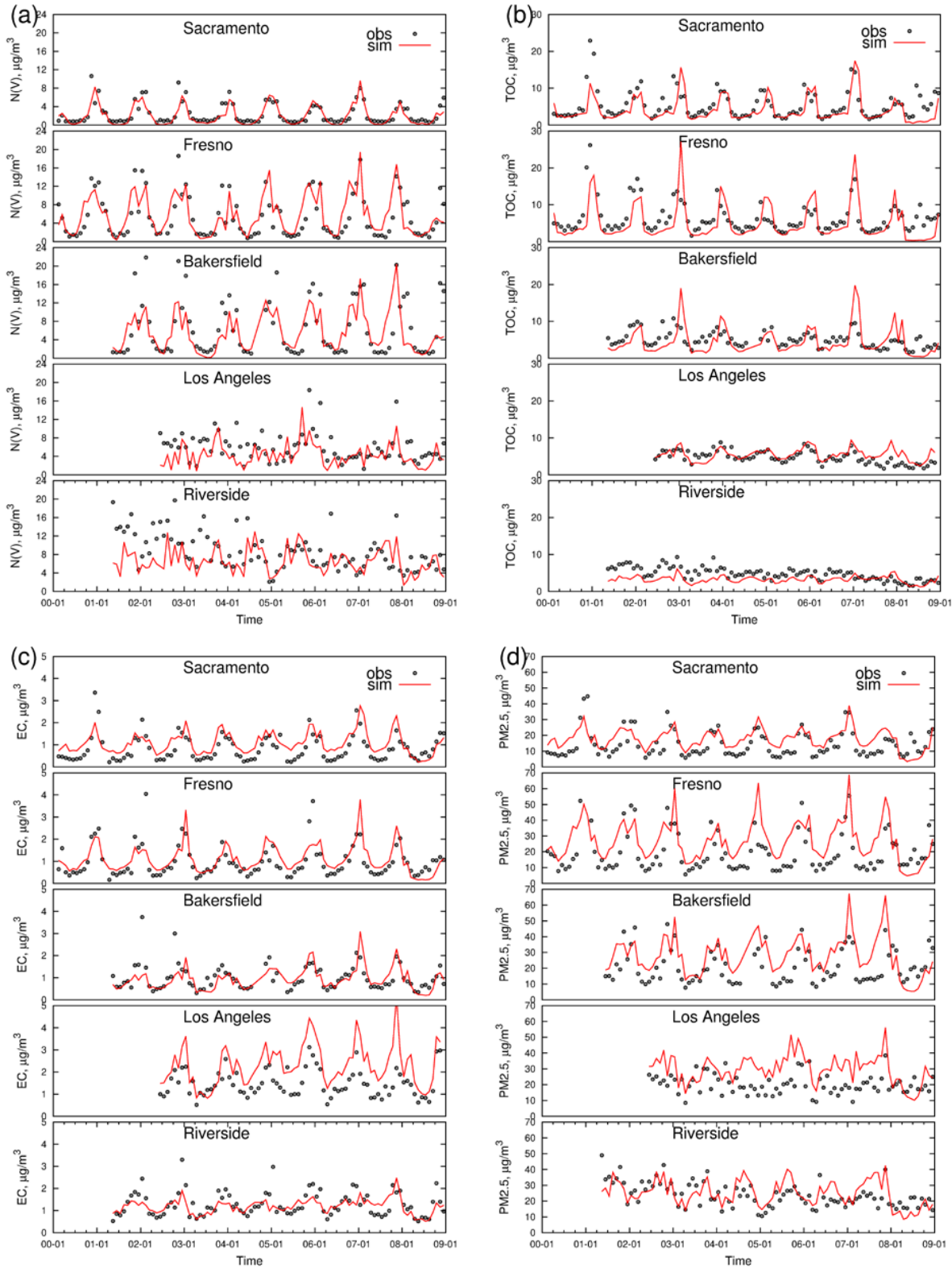

Figure 6. Predicted (red lines) vs. observed (dark dots) monthly average $\mathrm{PM}_{2.5}$ nitrate (a), OC (b), EC (c), and $\mathrm{PM}_{2.5}$ total mass (d) at Sacramento, Fresno, Bakersfield, Los Angeles, and Riverside.

istry). Unfortunately, the large variation in the correction factor among different locations suggests that these scaling factors cannot be simply interpolated/extrapolated from the indicated five monitoring sites to the full modeling domain.

Figures $5 \mathrm{~d}$ and $6 \mathrm{a}$ show the predicted and measured monthly average ammonium and nitrate concentrations. Ammonium nitrate is a major $\mathrm{PM}_{2.5}$ component in California, especially in wintertime when the low temperature and high relative humidity favor partitioning to the condensed phase. The monthly average ammonium and nitrate results demonstrate similar model performance. The predicted concentrations agree reasonably well with measured ambient concen- trations and seasonal variations. Model predictions are lower than measured values in the early years, especially during winter months when concentrations are highest. This pattern is very consistent with $\mathrm{CO}$ model performance, suggesting mobile emissions are under-estimated for the early years of the simulation period. Nitrate is formed through NO oxidation to nitric acid but NO concentrations are not underpredicted, suggesting that the chemical conversion of NO to nitric acid is too slow. Carter and Heo (2012) suggested that SAPRC11 mechanism systematically underpredicts $\mathrm{OH}$ radical concentrations by $\sim 30 \%$, which would be consistent with the observed trends. 

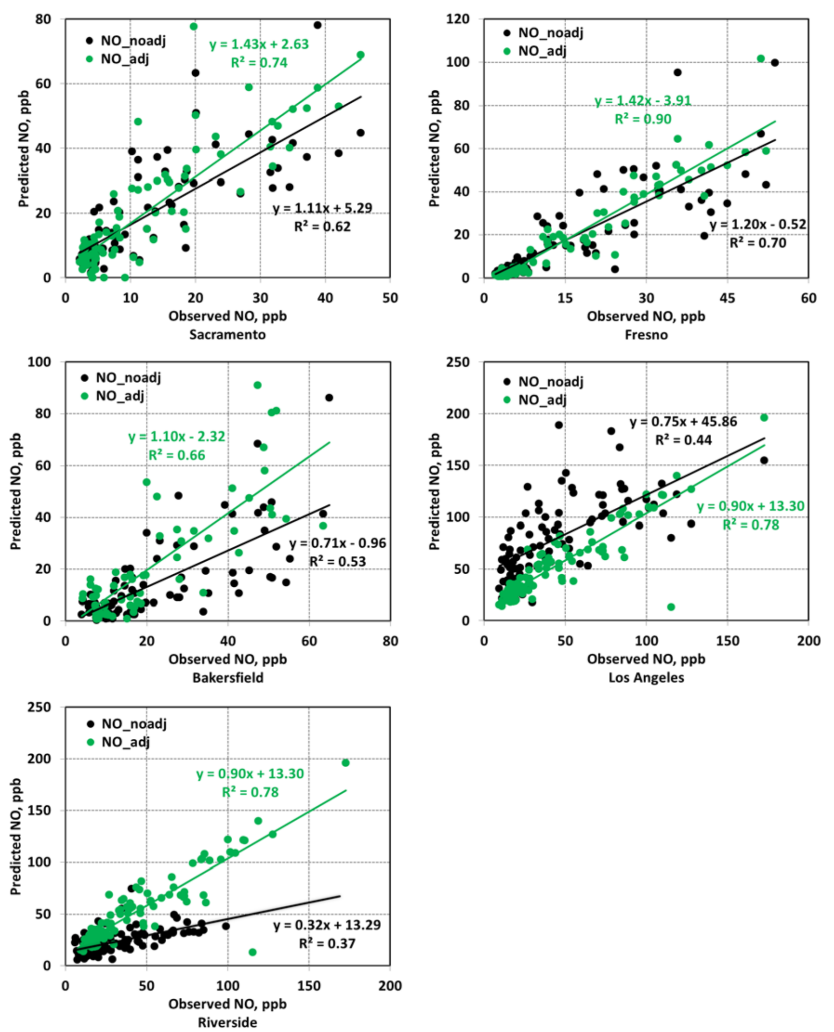

Figure 7. Monthly average NO concentrations adjusted with the predicted/observed $\mathrm{CO}$ ratios. NO_noadj represents the NO concentrations in the UCD/CIT model predictions, and NO_adj represents the NO concentrations adjusted with observations as $\mathrm{NO}$ adj = NO_noadj $\times$ CO_predicted $/$ CO_measured.

Gas-particle partitioning of ammonium nitrate depends on temperature and relative humidity. While there is no systematic bias in WRF temperature, relative humidity is generally underpredicted by up to $40 \%$ over California. A 1-year sensitivity analysis was conducted with RH increased uniformly by $+30 \%$ (but not to exceed $95 \%$, and all other meteorological parameters were kept the same) in 2008 to investigate the impact of the relative humidity bias on particulate nitrate predictions. The arbitrary increase in RH by $30 \%$ in the air quality model simulations yields an upper bound estimate of the nitrate sensitivity to RH. Figure 8 compares the monthly average nitrate concentrations predicted with the original $\mathrm{RH}$ (denoted as "RH_ori" case) and the enhanced RH (denoted as "RH +0.3 " case) at Sacramento and Fresno. Nitrate predictions are generally higher in the " $\mathrm{RH}+0.3$ " case due to more particle phase water available to absorb nitrate into the condensed phase. The nitrate predictions at Sacramento are significantly improved during most months in 2008, suggesting this area suffers from the low RH bias in the WRF predictions. Nitrate at Fresno is improved mostly in the winter and spring but is still underpredicted during the time period with peak winter concentrations, indicating this area is in-

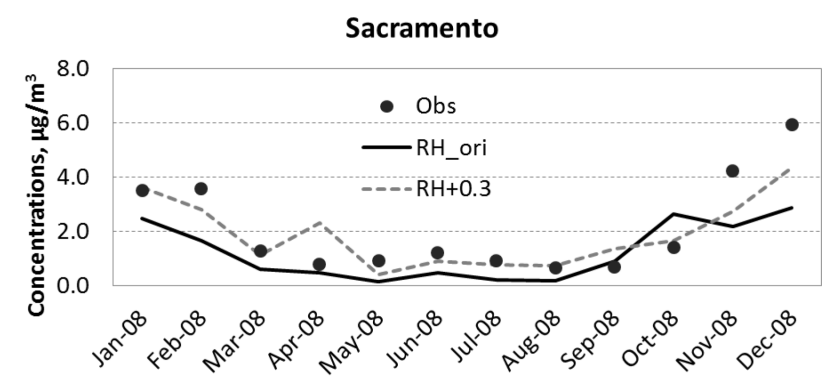

Fresno

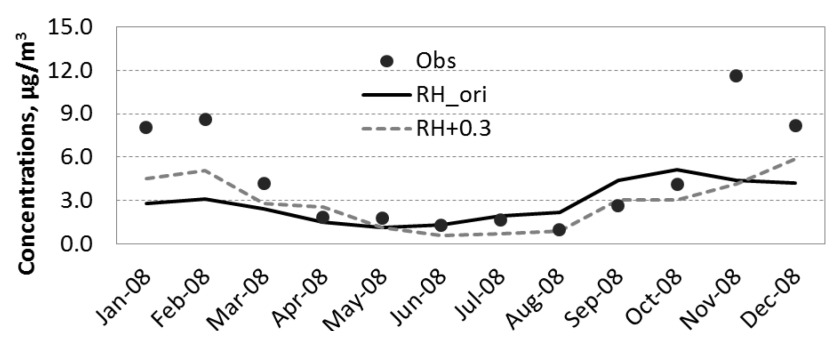

Figure 8. Monthly average nitrate concentrations in 2008 at Sacramento and Fresno, predicted with perturbed relative humidity $(\mathrm{RH}+0.3)$, compared to the base-case nitrate predictions (RH_ori) and observed concentrations (Obs).

fluenced by other factors besides RH. Nitrate predictions at Fresno in summer and fall are lower when RH is enhanced, due to faster deposition caused by larger particle sizes with more particle phase water. The uniform RH increase of 0.3 in this region is likely unrealistically large during these months.

Figure $6 \mathrm{~b}$ shows the OC predictions and measurements. Organic aerosol in California it is typically the second most abundant species after ammonium nitrate. In the comparison, an OM / OC ratio of 1.6 (Turpin and Lim, 2010) is applied to convert primary organic aerosol OM back to OC for comparison to measured concentrations. The conversion ratios for SOA species are taken from Table 1 in Carlton et al. (2010). Predicted OC agrees reasonably well with measured concentrations but is lower than the wintertime high concentrations in the early years, similar to other PM components. Predicted $\mathrm{OC}$ in summers is also in good agreement with measurements at the indicated monitoring sites. As mentioned previously, these sites are all near major freeways and therefore $\mathrm{OC}$ is dominated by primary organic aerosols. Larger bias is found at sites distant from local sources where SOA becomes more important. More analysis about the concentrations and sources of the $\mathrm{OC}$ results are included in a companion paper (Hu et al., 2015).

Figure $6 \mathrm{c}$ shows that predicted EC concentrations agree well with measured concentrations. High measured EC concentrations in a few winter months in the early years are underpredicted, but EC concentrations in the summer months are generally overpredicted.

Figure 6d shows that monthly average predictions for $\mathrm{PM}_{2.5}$ mass concentrations agree well with observations, and 
seasonal trends are generally captured with high concentrations in winter and low concentrations in summer. $\mathbf{P M}_{2.5}$ is overpredicted in summer months when nitrate, sulfate, and ammonium are found to be underpredicted. These trends reflect the overprediction of the primary components, mostly dust particles, in the model calculations (Hu et al., 2014a). This result suggests that a uniform scaling factor of 0.5 for dust emissions may not be appropriate. A smaller factor (for example, a factor of 0.25 was used in the eastern USA; Tesche et al., 2006) or a spatially resolved method that accounts for the land-use types (Pace, 2005) should be used for future studies in California.

California experiences the highest $\mathrm{PM}_{2.5}$ concentrations in wintertime, caused by stagnant meteorological conditions characterized by low wind speed and shallow atmospheric mixing layer. The WRF model tends to overpredict wind speed during low wind speed events $\left(\leq 2 \mathrm{~m} \mathrm{~s}^{-1}\right)$ in California (Zhao et al., 2011). Increasing $u^{*}$ by $50 \%$ improves the WRF wind prediction but still overpredicts wind speed during events when measured wind speed is $<1.5 \mathrm{~m} \mathrm{~s}^{-1}$. A zeroorder approximation of air pollutant concentration (Mahmud, 2010) is

$C=\frac{E}{V}=\frac{E}{u \times H}$,

where $C$ is the pollutant concentration, $E$ is the source pollutant emission rate, $V$ is the air ventilation rate which is equal to wind speed $\times$ mixing height, and $u$ and $H$ are the horizontal wind speed and mixing height, respectively. The concentration is linearly dependent on the inverse wind speed $(1 / u)$. Figure 9 shows the MFBs of the predicted atmospheric inverse wind speed $(1 / u)$ as a function of the observed atmospheric inverse wind speed. Also shown in Fig. 9 are the MFBs of PM component concentrations as a function of the observed concentrations. The MFBs decrease when the inverse wind speed or concentrations increase, indicating that low inverse wind speed/concentrations are overpredicted but high inverse wind speed /concentrations are underpredicted. The trends of inverse wind speed and concentrations are well correlated, indicating that simple wind bias leads to bias in PM predictions, especially during the events with high PM pollution. The correlation with $1 / u$ MFB is stronger for primary PM component(s) than for secondary components, indicating that additional processes affect the secondary PM, e.g., chemistry and gas-particle partitioning. Sulfate bias has the weakest correlation to inverse ventilation bias, because sulfate bias is mainly driven by the bias in sulfur emissions.

Figure 10 shows the predicted 9-year average concentrations of $\mathrm{PM}_{2.5}$, EC, OC, nitrate, sulfate, and ammonium compared with measured average concentrations over California. High concentrations of all PM pollutants occur in the urban areas with large population, indicating that most of the PM is generated by anthropogenic activities. The predicted spatial distributions generally agree well with measurements but provide much more detailed information. $\mathrm{PM}_{2.5}$ concentra-

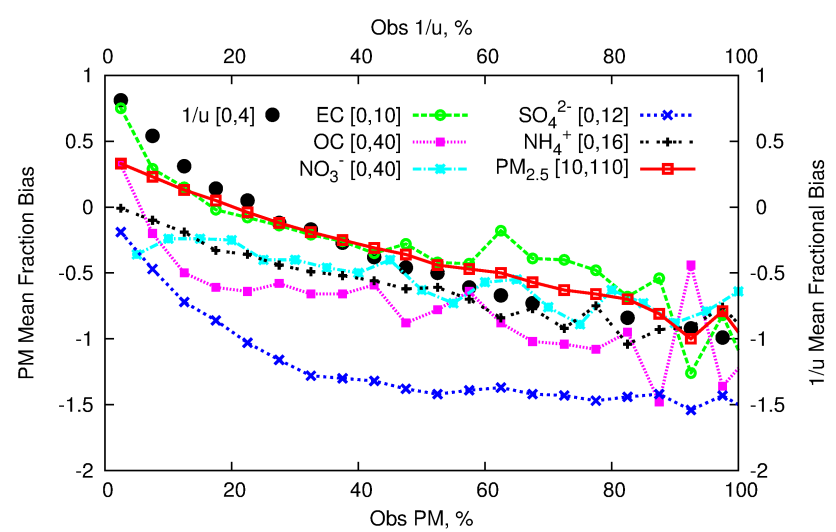

Figure 9. Association between predicted PM concentration bias and wind bias vs. observed values. The observed PM concentrations and $1 / u$ values on the $x$ axis are expressed in a relative scale of $0-100 \%$ of maximum range calculated as $x(\%)=$ $\left(\mathrm{C}-\mathrm{C}_{\min }\right) /\left(\mathrm{C}_{\max }-\mathrm{C}_{\min }\right) \times 100$. Values for $\left[\mathrm{C}_{\min }, \mathrm{C}_{\max }\right]$ are listed in the concentration key. Bias between predicted vs. observed values is shown on the $y$ axis. Ideal behavior is bias of zero at all concentrations and wind speeds.

tions are overpredicted in the SJV air basin due to an overprediction of agricultural dust. High OC concentrations were measured at two sites in Northern California due to intense wood burning. The two sites are in the $24 \mathrm{~km}$ model domain but outside the $4 \mathrm{~km}$; therefore the predicted OC concentrations in the $24 \mathrm{~km}$ grids do not agree well with the measurements at this location. This finding confirms that $24 \mathrm{~km}$ resolution is probably too coarse for studies of health effects and justifies the use of $4 \mathrm{~km}$ grids over the majority of California's population in the current work. Background sulfate concentrations at IMPROVE sites were measured to be $0.6-1 \mu \mathrm{g} \mathrm{m}^{-3}$, but higher concentrations of $2-3 \mu \mathrm{g} \mathrm{m}^{-3}$ were measured in Southern California. Model calculations do not reproduce this concentration enhancement, leading to an underprediction in the concentrations of this $\mathrm{PM}_{2.5}$ species.

\subsection{Discussion}

In general, the reasonable agreement between model predictions and measurement builds confidence that the model predictions can provide a reasonable estimate of exposure fields in locations with no available measurements. The detailed analysis described in the previous section identifies several aspects that must be considered when applying the data in the health effect studies. For the gaseous pollutants, daily maximum $\mathrm{O}_{3}$ predictions are in good agreement with measurements across the entire modeling domain. Seasonal and annual variations are captured accurately. Therefore daily maximum $\mathrm{O}_{3}$ predictions can be used in health analyses with high confidence. The predictions also capture the seasonal variations in NO and $\mathrm{CO}$ but do not reflect the long-term trends, especially in Southern California. Predicted monthly aver- 


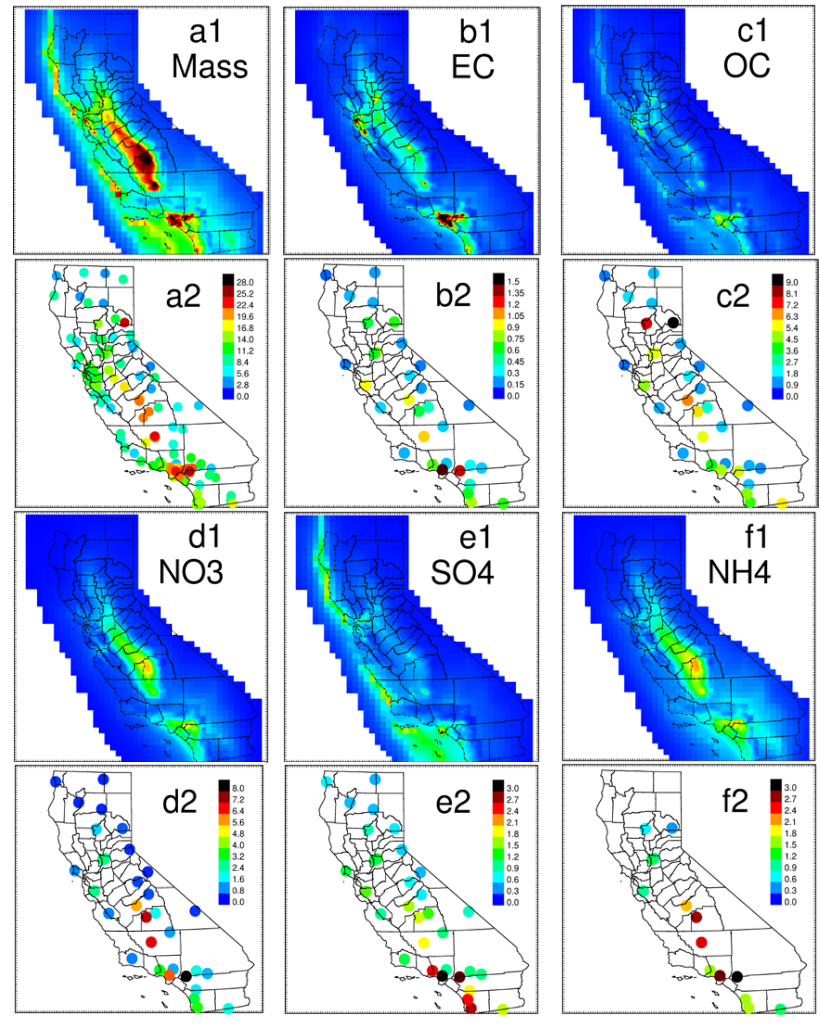

Figure 10. Predicted (1) vs. measured (2) 9-year average $\mathrm{PM}_{2.5}$ total mass (a), EC (b), OC (c), nitrate (d), sulfate (e), and ammonium (f) concentrations. The SoCAB_4 km and SJV_4 km results are overlayed on top of CA_24 km results to create the model predicted spatial distributions. Predicted and measured concentrations of the same species are in the same scale shown in the measurement panels.

ages of $\mathrm{NO}$ and $\mathrm{CO}$ in Northern California are preferred over daily averages for use in health analyses. For the PM pollutants, daily concentrations and spatial distributions of EC and total $\mathrm{PM}_{2.5}$ mass generally agree well with observations, but monthly averages should be considered first in health studies as they are in better agreement with observations than shorter averages. Predicted OC in winter is also reasonably accurate, but OC in summer should be used with caution. Sulfate and nitrate are both underpredicted. Sulfate has greater bias in Southern California than in Northern California, while nitrate has consistent bias throughout the modeling domain. This suggests that the spatial distribution information of nitrate might still be useful for health effect studies that use contrasts in exposure as a function of location, but sulfate data are likely not useful in health effect studies at the present time.

Predicted monthly averages for PM concentrations are more accurate than daily averages, suggesting that the PM exposure predictions will be most useful in studies that can take advantage of averaging times $\geq 30$ days. Longer averaging times smooth out short-term PM variations that could be useful in some epidemiological studies that focus on short term changes in health effects. To get more accurate pollutant predictions at shorter timescales would require more accurate representation of emissions, meteorological conditions, and atmospheric chemistry at these time scales. Many intensive studies that manually corrected input data have focused on high temporal resolution for short periods (generally less than 1 month), such as the California Regional $\mathrm{PM}_{10} / \mathrm{PM}_{2.5}$ Air Quality Study (Ying et al., 2008). It is currently impractical to carry out such efforts for a $\sim 10$-year modeling period in which there are a large number of special events that are not represented by automated meteorology and emissions models. The atmospheric modeling community continues to refine tools that can capture and accurately represent these special cases. For example, the current study includes automatic detection and incorporation of wildfire emissions into the modeling system based on satellite observations. This automated feature was not generally available in previous studies. Future advances will detect transportation patterns responding to traffic accidents or holiday traffic jams, drought effects on biogenic emissions, etc. These future advances will improve models to have more accurate predictions in both short (<1 month) and long ( $>1$ month) averaging times.

\section{Conclusions}

For the first time, a $\sim$ decadal (9-year) CTM air quality model simulation with $4 \mathrm{~km}$ horizontal resolution over populated regions has been conducted in California to provide air quality data for health effect studies. Model predictions are compared to measurements in order to evaluate both the spatial and temporal accuracy of the results. The performance of the source-oriented UCD/CIT air quality model is satisfactory for $\mathrm{O}_{3}, \mathrm{PM}_{2.5}$, and $\mathrm{EC}$ (both spatially and temporally). Predicted OC, nitrate, and ammonium are less satisfactory but generally meet standard model performance criteria. OC bias is larger in summertime than wintertime mainly due to an incomplete understanding of SOA formation mechanisms. Bias in predicted ammonium nitrate is associated with uncertainties in emissions, the WRF-predicted relative humidity fields, and the chemistry mechanism. Predicted sulfate is not satisfactory due to missing sulfur sources in the emissions. The CO and NO (species dominated by mobile emissions) results reveal significant temporal and spatial uncertainties associated with the mobile emissions generated by the EMFAC 2007 model. The WRF model tends to overpredict wind speed during stagnation events, leading to underpredictions of high PM concentrations usually in winter months. The WRF model also generally underpredicts relative humidity, resulting in less particulate nitrate formation especially during winter months. Despite the issues noted above, predicted spatial distributions of PM components are in reasonably good agreement with measurements. Predicted seasonal and annual variations also generally agree well with mea- 
surements. Better model performance with longer averaging time is found in the predictions, suggesting that model results with averaging times $\geq 1$ month should be first considered in epidemiological studies. All model results included in the current manuscript can be downloaded free of charge at http://faculty.engineering.ucdavis.edu/kleeman/.

Acknowledgements. This study was funded by the United States Environmental Protection Agency under grant no. 83386401. Although the research described in the article has been funded by the United States Environmental Protection Agency, it has not been subject to the agency's required peer and policy review and therefore does not necessarily reflect the reviews of the agency and no official endorsement should be inferred.

Edited by: C. H. Song

\section{References}

Anenberg, S. C., Horowitz, L. W., Tong, D. Q., and West, J. J.: An Estimate of the Global Burden of Anthropogenic Ozone and Fine Particulate Matter on Premature Human Mortality Using Atmospheric Modeling, Environ. Health Persp., 118, 1189-1195, 2010.

Angevine, W. M., Eddington, L., Durkee, K., Fairall, C., Bianco, L., and Brioude, J.: Meteorological Model Evaluation for CalNex 2010, Mon. Weather Rev., 140, 3885-3906, 2012.

Appel, K. W., Bhave, P. V., Gilliland, A. B., Sarwar, G., and Roselle, S. J.: Evaluation of the community multiscale air quality (CMAQ) model version 4.5: Sensitivities impacting model performance; Part II - particulate matter, Atmos. Environ., 42, 6057-6066, 2008.

Bao, J. W., Michelson, S. A., Persson, P. O. G., Djalalova, I. V., and Wilczak, J. M.: Observed and WRF-simulated low-level winds in a high-ozone episode during the Central California Ozone Study, J. Appl. Meteorol. Clim., 47, 2372-2394, 2008.

Barnett, A. G., Plonka, K., Seow, W. K., Wilson, L. A., and Hansen, C.: Increased traffic exposure and negative birth outcomes: a prospective cohort in Australia, Environ. Health, 10:26, doi:10.1186/1476-069X-10-26, 2011.

Bates, T. S., Lamb, B. K., Guenther, A., Dignon, J., and Stoiber, R. E.: Sulfur emissions to the atmosphere from natural sourees, J. Atmos. Chem., 14, 315-337, 1992.

Beelen, R., Hoek, G., van den Brandt, P. A., Goldbohm, R. A., Fischer, P., Schouten, L. J., Armstrong, B., and Brunekreef, B.: Long-term exposure to traffic-related air pollution and lung cancer risk, Epidemiology, 19, 702-710, 2008.

Beeson, W. L., Abbey, D. E., and Knutsen, S. F.: Long-term concentrations of ambient air pollutants and incident lung cancer in California adults: Results from the AHSMOG study, Environ. Health Persp., 106, 813-822, 1998.

Beevers, S. D., Kitwiroon, N., Williams, M. L., Kelly, F. J., Ross Anderson, H., and Carslaw, D. C.: Air pollution dispersion models for human exposure predictions in London, J. Expos. Sci. Environ. Epidemiol., 23, 647-653, 2013.

Bell, M. L., Dominici, F., Ebisu, K., Zeger, S. L., and Samet, J. M.: Spatial and temporal variation in $\operatorname{PM}(2.5)$ chemical composition in the United States for health effects studies, Environ. Health Persp., 115, 989-995, 2007.

Bell, M. L., Belanger, K., Ebisu, K., Gent, J. F., Lee, H. J., Koutrakis, P., and Leaderer, B. P.: Prenatal exposure to fine particulate matter and birth weight: variations by particulate constituents and sources, Epidemiology, 21, 884-891, 2010.

Boylan, J. W. and Russell, A. G.: PM and light extinction model performance metrics, goals, and criteria for three-dimensional air quality models, Atmos. Environ., 40, 4946-4959, 2006.

Brauer, M., Lencar, C., Tamburic, L., Koehoorn, M., Demers, P., and Karr, C.: A cohort study of traffic-related air pollution impacts on birth outcomes, Environ. Health Persp., 116, 680-686, 2008.

Bravo, M. A., Fuentes, M., Zhang, Y., Burr, M. J., and Bell, M. L.: Comparison of exposure estimation methods for air pollutants: Ambient monitoring data and regional air quality simulation, Environ. Res., 3, 116, 1-10, 2012.

Burnett, R. T., Brook, J., Dann, T., Delocla, C., Philips, O., Cakmak, S., Vincent, R., Goldberg, M. S., and Krewski, D.: Association between particulate- and gas-phase components of urban air pollution and daily mortality in eight Canadian cities, Inhal. Toxicol., 12, 15-39, 2000.

Cao, J. J., Xu, H. M., Xu, Q., Chen, B. H., and Kan, H. D.: Fine Particulate Matter Constituents and Cardiopulmonary Mortality in a Heavily Polluted Chinese City, Environ. Health Persp., 120, 373-378, 2012.

CARB: Calculating emission inventories for vehicles in California, User's Guide EMFAC 2007 version 2.30 last access: 2010, 2008

CARB: Meteorology Data Query Tool (PST), http://www.arb.ca. gov/aqmis2/metselect.php (last access: 2011), 2011a.

CARB: Database: California Air Quality Data - Selected Data Available for Download at http://www.arb.ca.gov/aqd/aqded/ aqdeddld.htm> |protectlkern+.1667em\relax (last access: 2011), 2011b.

CARB: Almanac Emission Projection Data (published in 2009), http://www.arb.ca.gov/app/emsinv/emssumcat.php (last access: 2012), 2012.

Cao, J., Yang, C., Li, J., Chen, R., Chen, B., Gu, D., Kan, H.: Association between long-term exposure to outdoor air pollution and mortality in China: a cohort study, J. Hazard Mater., 186, 15941600, 2011.

Carlton, A. G., Bhave, P. V., Napelenok, S. L., Edney, E. D., Sarwar, G., Pinder, R. W., Pouliot, G. A., and Houyoux, M.: Model Representation of Secondary Organic Aerosol in CMAQv4.7, Environ. Sci. Tech. Lib., 44, 8553-8560, 2010.

Carter, W. P. L. and Heo, G.: Development of revised SAPRC Aromatics mechanisms, Final Report to California Air Resources Board Contracts No. 07-730 and 08-326, 2010.

Carter, W. P. L. and Heo, G.: Development of revised SAPRC aromatics mechanisms, Atmos. Environ., 77, 404-414, 2013.

Chen, J. J., Ying, Q., and Kleeman, M. J.: Source apportionment of wintertime secondary organic aerosol during the California regional PM(10)/PM(2.5) air quality study, Atmos. Environ., 44, 1331-1340, 2010.

Chen, J., Lu, J., Avise, J. C., DaMassa, J. A., Kleeman, M. J., and Kaduwela, A. P.: Seasonal modeling of $\mathrm{PM}_{2.5}$ in California's San Joaquin Valley, Atmos. Environ., 92, 182-190, 2014.

Chen, Y. Y., Ebenstein, A., Greenstone, M., and Li, H. B.: Evidence on the impact of sustained exposure to air pollution on 
life expectancy from China's Huai River policy, P. Natl. Acad. Sci. USA, 110, 12936-12941, 2013.

Cooper, J. A. E. A.: Dinal Appendix V-G, PM $_{10}$ source composition library for the South Coast Air Basin, Technical Report, South Coast Air Quality Management District, Diamond Bar, California, 1989.

Correia, A. W., Pope, C. A., Dockery, D. W., Wang, Y., Ezzati, M., and Dominici, F.: Effect of Air Pollution Control on Life Expectancy in the United States An Analysis of 545 US Counties for the Period from 2000 to 2007, Epidemiology, 24, 23-31, 2013.

Countess, R. J.: Reconciling Fugitive Dust Emission Inventories with Ambient Measurements, 12th Annual EPA Emission Inventory Conference San Diego, CA, 2003.

Day, D. A., Liu, S., Russell, L. M., and Ziemann, P. J.: Organonitrate group concentrations in submicron particles with high nitrate and organic fractions in coastal southern California, Atmos. Environ., 44, 1970-1979, 2010.

de Leeuw, G., Neele, F. P., Hill, M., Smith, M. H., and Vignali, E.: Production of sea spray aerosol in the surf zone, J. Geophys. Res.-Atmos., 105, 29397-29409, 2000.

Dockery, D. W.: Epidemiologic evidence of cardiovascular effects of particulate air pollution, Environ. Health Persp., 109, 483486, 2001.

Dockery, D. W., Pope, C. A., Xu, X. P., Spengler, J. D., Ware, J. H., Fay, M. E., Ferris, B. G., and Speizer, F. E.: An Association between Air-Pollution and Mortality in 6 United-States Cities, New Engl. J. Med., 329, 1753-1759, 1993.

Emery, C., Tai, E., and Yarwood, G.: Enhanced meteorological modeling and performance evaluation for two texas episodes, in: Report to the Texas Natural Resources Conservation Commission, p.b.E., edited by: Internatioanl Corp, Novato, CA, 2001.

EPA, U.S.: Particulate Matter $\left(\mathrm{PM}_{2.5}\right)$ Area Information (2006 Standard), http://www.epa.gov/airquality/greenbook/rindex.html (last acess: 2014), 2013.

Fann, N., Lamson, A. D., Anenberg, S. C., Wesson, K., Risley, D., and Hubbell, B. J.: Estimating the National Public Health Burden Associated with Exposure to Ambient $\mathrm{PM}_{2.5}$ and Ozone, Risk Anal., 32, 81-95, 2012.

Fast, J. D., Allan, J., Bahreini, R., Craven, J., Emmons, L., Ferrare, R., Hayes, P. L., Hodzic, A., Holloway, J., Hostetler, C., Jimenez, J. L., Jonsson, H., Liu, S., Liu, Y., Metcalf, A., Middlebrook, A., Nowak, J., Pekour, M., Perring, A., Russell, L., Sedlacek, A., Seinfeld, J., Setyan, A., Shilling, J., Shrivastava, M., Springston, S., Song, C., Subramanian, R., Taylor, J. W., Vinoj, V., Yang, Q., Zaveri, R. A., and Zhang, Q.: Modeling regional aerosol and aerosol precursor variability over California and its sensitivity to emissions and long-range transport during the $2010 \mathrm{CalNex}$ and CARES campaigns, Atmos. Chem. Phys., 14, 10013-10060, doi:10.5194/acp-14-10013-2014, 2014.

Ford, I., Li, X. Y., Donaldson, K., MacNee, W., Seaton, A., and Greaves, M.: Particulate air pollution and cardiovascular risk: Increased factor VIIc follows exposure to ultrafine particles, Brit. J. Haematol., 101, p. 148, 1998.

Franchini, M. and Mannucci, P. M.: Particulate Air Pollution and Cardiovascular Risk: Short-term and Long-term Effects, Semin. Thromb. Hemost., 35, 665-670, 2009.

Frank, N. H.: Retained nitrate, hydrated sulfates, and carbonaceous mass in Federal Reference Method fine particulate matter for six eastern US cities, J. Air Waste Manage. Assoc., 56, 500-511, 2006.

Franklin, M., Zeka, A., and Schwartz, J.: Association between $\mathrm{PM}_{2.5}$ and all-cause and specific-cause mortality in 27 US communities, J. Expo. Sci. Env. Epid., 17, 279-287, 2007.

Franklin, M., Koutrakis, P., and Schwartz, J.: The role of particle composition on the association between $\mathrm{PM}_{2.5}$ and mortality, Epidemiology, 19, 680-689, 2008.

Goldgewicht, C.: Association between surrounding air pollution and daily mortality in subjects with diabetes and cardiovascular complications, Envir. Risques Sante., 6, 15-16, 2007.

Gong, S. L.: A parameterization of sea-salt aerosol source function for sub- and super-micron particles, Global Biogeochem. Cy., 17, 8-1-8-7 doi:10.1029/2003GB002079, 2003.

Gordian, M. E., Ozkaynak, H., Xue, J. P., Morris, S. S., and Spengler, J. D.: Particulate air pollution and respiratory disease in Anchorage, Alaska, Environ. Health Persp., 104, 290-297, 1996.

Hacon, S., Ornelas, C., Ignotti, E., and Longo, K.: Fine particulate air pollution and hospital admission for respiratory diseases in the Amazon region, Epidemiology, 18, p. 81, 2007.

Harley, R. A., Hannigan, M. P., and Cass, G. R.: Respeciation of Organic Gas Emissions and the Detection of Excess Unburned Gasoline in the Atmosphere, Environ. Sci. Tech., 26, 2395-2408, 1992.

Held, T., Ying, Q., Kaduwela, A., and Kleeman, M.: Modeling particulate matter in the San Joaquin Valley with a source-oriented externally mixed three-dimensional photochemical grid model, Atmos. Environ., 38, 3689-3711, 2004.

Held, T., Ying, Q., Kleeman, M. J., Schauer, J. J., and Fraser, M. P.: A comparison of the UCD/CIT air quality model and the CMB source-receptor model for primary airborne particulate matter, Atmos. Environ., 39, 2281-2297, 2005.

Hildemann, L. M., Markowski, G. R., and Cass, G. R.: ChemicalComposition of Emissions from Urban Sources of Fine Organic Aerosol, Environ. Sci. Tech., 25, 744-759, 1991a.

Hildemann, L. M., Markowski, G. R., Jones, M. C., and Cass, G. R.: Submicrometer Aerosol Mass Distributions of Emissions from Boilers, Fireplaces, Automobiles, Diesel Trucks, and MeatCooking Operations, Aerosol Sci. Tech., 14, 138-152, $1991 \mathrm{~b}$.

Hixson, M., Mahmud, A., Hu, J., Bai, S., Niemeier, D. A., Handy, S. L., Gao, S., Lund, J. R., Sullivan, D. C., and Kleeman, M. J.: Influence of regional development policies and clean technology adoption on future air pollution exposure, Atmos. Environ., 44, 552-562, 2010.

Hixson, M., Mahmud, A., Hu, J., and Kleeman, M. J.: Resolving the interactions between population density and air pollution emissions controls in the San Joaquin Valley, USA, J. Air Waste Manage. Assoc., 62, 566-575, 2012.

Hodzic, A., Madronich, S., Bohn, B., Massie, S., Menut, L., and Wiedinmyer, C.: Wildfire particulate matter in Europe during summer 2003: meso-scale modeling of smoke emissions, transport and radiative effects, Atmos. Chem. Phys., 7, 4043-4064, doi:10.5194/acp-7-4043-2007, 2007.

Houck, J. E., Chow, J. C., Watson, J. G., Simons, C. A., Prichett, L. C., Goulet, J. M., Frazier, C. A.: Determination of particle size distribution and chemical composition of particulate matter from selected sources in California. Technical Report, Contract A6-175-32, California Air Resources Board, OMNI Envi- 
ronment Service Incorporate, Desert Research Institute, Beaverton, Oregon, 1989.

Hu, J., Ying, Q., Chen, J. J., Mahmud, A., Zhao, Z., Chen, S. H., and Kleeman, M. J.: Particulate air quality model predictions using prognostic vs. diagnostic meteorology in central California, Atmos. Environ., 44, 215-226, 2010.

Hu, J., Howard, C. J., Mitloehner, F., Green, P. G., and Kleeman, M. J.: Mobile Source and Livestock Feed Contributions to Regional Ozone Formation in Central California, Environ. Sci. Tech., 46, 2781-2789, 2012.

Hu, J., Zhang, H., Chen, S.-H., Vandenberghe, F., Ying, Q., and Kleeman, M. J.: Predicting Primary $\mathrm{PM}_{2.5}$ and $\mathrm{PM}_{0.1}$ Trace Composition for Epidemiological Studies in California, Environ. Sci. Tech., 48, 4971-4979, 2014a.

Hu, J., Zhang, H., Chen, S., Ying, Q., Vandenberghe, F., and Kleeman, M. J.: Identifying $\mathrm{PM}_{2.5}$ and $\mathrm{PM}_{0.1}$ Sources for Epidemiological Studies in California, Environ. Sci. Technol., 48, 49804990, 2014b.

Hu, J. L., Zhang, H. L., Chen, S. H., Wiedinmyer, C., Vandenberghe, F., Ying, Q., and Kleeman, M. J.: Long-term Particulate Matter Modeling for Health Effects Studies in California - Part II: Concentrations and Souces of Primary and Secondary Organic Aerosols, in preparation 2015.

Ito, K., Mathes, R., Ross, Z., Nadas, A., Thurston, G., and Matte, T.: Fine Particulate Matter Constituents Associated with Cardiovascular Hospitalizations and Mortality in New York City, Environ. Health Persp., 119, 467-473, 2011.

Kleeman, M. J. and Cass, G. R.: Source contributions to the size and composition distribution of urban particulate air pollution, Atmos. Environ., 32, 2803-2816, 1998.

Kleeman, M. J. and Cass, G. R.: A 3D Eulerian source-oriented model for an externally mixed aerosol, Environ. Sci. Technol., 35, 4834-4848, 2001.

Kleeman, M. J., Cass, G. R., and Eldering, A.: Modeling the airborne particle complex as a source-oriented external mixture., J. Geophys. Res.-Atmos., 102, 21355-21372, 1997.

Kleeman, M. J., Schauer, J. J., and Cass, G. R.: Size and composition distribution of fine particulate matter emitted from wood burning, meat charbroiling, and cigarettes, Environ. Sci. Technol., 33, 3516-3523, 1999.

Kleeman, M. J., Schauer, J. J., and Cass, G. R.: Size and composition distribution of fine particulate matter emitted from motor vehicles, Environ. Sci. Technol., 34, 1132-1142, 2000.

Kleeman, M. J., Ying, Q., Lu, J., Mysliwiec, M. J., Griffin, R. J., Chen, J. J., and Clegg, S.: Source apportionment of secondary organic aerosol during a severe photochemical smog episode, Atmos. Environ., 41, 576-591, 2007.

Kleeman, M. J., Robert, M. A., Riddle, S. G., Fine, P. M., Hays, M. D., Schauer, J. J., and Hannigan, M. P.: Size distribution of trace organic species emitted from biomass combustion and meat charbroiling, Atmos. Environ., 42, 3059-3075, 2008.

Krall, J. R., Anderson, G. B., Dominici, F., Bell, M. L., and Peng, R. D.: Short-term Exposure to Particulate Matter Constituents and Mortality in a National Study of US Urban Communities, Environ. Health Persp., 121, 1148-1153, 2013.

Laden, F., Neas, L. M., Dockery, D. W., and Schwartz, J.: Association of fine particulate matter from different sources with daily mortality in six US cities, Environ. Health Persp., 108, 941-947, 2000.
Langrish, J. P., Bosson, J., Unosson, J., Muala, A., Newby, D. E., Mills, N. L., Blomberg, A., and Sandstrom, T.: Cardiovascular effects of particulate air pollution exposure: time course and underlying mechanisms, J. Intern. Med., 272, 224-239, 2012.

Laurent, O., Wu, J., Li, L., Chung, J., and Bartell, S.: Investigating the association between birth weight and complementary air pollution metrics: a cohort study, Environ. Health, 12, P. 18, doi:10.1186/1476-069X-12-18, 2013.

Laurent, O., Hu, J., Li, L., Cockburn, M., Escobedo, L., Kleeman, M., and Wu, J.: Sources and contents of air pollution affecting term low birth weight in Los Angeles County, California, 2001-2008, Environ, Res., 134, 488-495, doi:10.1016/j.envres.2014.05.003, 2014.

Le Tertre, A., Medina, S., Samoli, E., Forsberg, B., Michelozzi, P., Boumghar, A., Vonk, J. M., Bellini, A., Atkinson, R., Ayres, J. G., Sunyer, J., Schwartz, J., and Katsouyanni, K.: Short-term effects of particulate air pollution on cardiovascular diseases in eight European cities, J. Epidemiol. Commun. H, 56, 773-779, 2002.

Levy, J. I., Diez, D., Dou, Y. P., Barr, C. D., Dominici, F.: A MetaAnalysis and Multisite Time-Series Analysis of the Differential Toxicity of Major Fine Particulate Matter Constituents, Am. J. Epidemiol., 175, 1091-1099, 2012.

Mahmud, A., Hixson, M., Hu, J., Zhao, Z., Chen, S.-H., and Kleeman, M. J.: Climate impact on airborne particulate matter concentrations in California using seven year analysis periods, Atmos. Chem. Phys., 10, 11097-11114, doi:10.5194/acp10-11097-2010, 2010.

Mar, T. F., Norris, G. A., Koenig, J. Q., and Larson, T. V.: Associations between air pollution and mortality in Phoenix, 1995-1997, Environ. Health Persp., 108, 347-353, 2000.

Mass, C. and Ovens, D.: WRF model physics: progress, problems, and perhaps some solutions, the 11th WRF Users' Workshop, 21-25 June, Boulder, CO, 2010.

Matsui, H., Koike, M., Takegawa, N., Kondo, Y., Griffin, R. J., Miyazaki, Y., Yokouchi, Y., and Ohara, T.: Secondary organic aerosol formation in urban air: Temporal variations and possible contributions from unidentified hydrocarbons, J. Geophys. Res.Atmos., 114, D04201, doi:10.1029/2008JD010164, 2009.

Michelson, S. A., Djalalova, I. V., and Bao, J.-W.: Evaluation of the Summertime Low-Level Winds Simulated by MM5 in the Central Valley of California, J. Appl. Meteorol. Clim., 49, 2230 2245, 2010.

Millstein, D. E. and Harley, R. A.: Revised estimates of construction activity and emissions: Effects on ozone and elemental carbon concentrations in southern California, Atmos. Environ., 43, 6328-6335, 2009.

Mysliwiec, M. J. and Kleeman, M. J.: Source apportionment of secondary airborne particulate matter in a polluted atmosphere, Environ. Sci. Technol., 36, 5376-5384, 2002.

Ostro, B., Broadwin, R., Green, S., Feng, W. Y., and Lipsett, M.: Fine particulate air pollution and mortality in nine California counties: Results from CALFINE, Environ. Health Persp., 114, 29-33, 2006.

Ostro, B., Feng, W. Y., Broadwin, R., Green, S., and Lipsett, M.: The effects of components of fine particulate air pollution on mortality in California: Results from CALFINE, Environ. Health Persp., 115, 13-19, 2007. 
Ostro, B., Lipsett, M., Reynolds, P., Goldberg, D., Hertz, A., Garcia, C., Henderson, K. D., and Bernstein, L.: Long-Term Exposure to Constituents of Fine Particulate Air Pollution and Mortality: Results from the California Teachers Study, Environ. Health Persp., 118, 363-369, 2010.

Pace, T. G.: Methodology to Estimate the Transportable Fraction (TF) of Fugitive Dust Emissions for Regional and Urban Scale Air Quality Analyses, US EPA August 2005, 2005.

Pope, C. A., Burnett, R. T., Thun, M. J., Calle, E. E., Krewski, D., Ito, K., and Thurston, G. D.: Lung cancer, cardiopulmonary mortality, and long-term exposure to fine particulate air pollution, J. Am. Med. Assoc., 287, 1132-1141, 2002.

Pope, C. A., Ezzati, M., Dockery, D. W.: Fine-Particulate Air Pollution and Life Expectancy in the United States, New Engl. J. Med., 360, 376-386, 2009.

Rasmussen, D. J., Hu, J., Mahmud, A., and Kleeman, M. J.: The Ozone-Climate Penalty: Past, Present, and Future, Environ. Sci. Technol., 47, 14258-14266, 2013.

Robert, M. A., Kleeman, M. J., and Jakober, C. A.: Size and composition distributions of particulate matter emissions: Part 2 Heavy-duty diesel vehicles, J. Air Waste Manage. Assoc., 57, 1429-1438, 2007a.

Robert, M. A., Van Bergen, S., Kleeman, M. J., and Jakober, C. A.: Size and composition distributions of particulate matter emissions: Part 1 - Light-duty gasoline vehicles, J. Air Waste Manage. Assoc., 57, 1414-1428, 2007b.

Sarnat, J. A., Sarnat, S. E., Crooks, J., Isakov, V., Touma, J., Ozkaynak, H., Mulholland, J., Russell, A., and Kewada, P.: Associations Between Spatially Resolved Estimates of Traffic-related Pollution and Acute Morbidity: Assessing Agreement of Results Among Multiple Exposure Assignment Approaches, Epidemiology, 22, 31-32, 2011.

Schauer, J. J., Kleeman, M. J., Cass, G. R., and Simoneit, B. R. T.: Measurement of emissions from air pollution sources. 1. C-1 through C-29 organic compounds from meat charbroiling, Environ. Sci. Technol., 33, 1566-1577, 1999a.

Schauer, J. J., Kleeman, M. J., Cass, G. R., and Simoneit, B. R. T.: Measurement of emissions from air pollution sources. 2. C1 through C-30 organic compounds from medium duty diesel trucks, Environ. Sci. Technol., 33, 1578-1587, 1999b.

Schauer, J. J., Kleeman, M. J., Cass, G. R., Simoneit, B. R. T.: Measurement of emissions from air pollution sources. 3. C-1-C-29 organic compounds from fireplace combustion of wood, Environ. Sci. Technol., 35, 1716-1728, 2001.

Schauer, J. J., Kleeman, M. J., Cass, G. R., and Simoneit, B. R. T.: Measurement of emissions from air pollution sources. 4. C-1-C27 organic compounds from cooking with seed oils, Environ. Sci. Technol., 36, 567-575, 2002a.

Schauer, J. J., Kleeman, M. J., Cass, G. R., and Simoneit, B. R. T.: Measurement of emissions from air pollution sources. 5. C-1-C32 organic compounds from gasoline-powered motor vehicles, Environ. Sci. Technol., 36, 1169-1180, 2002b.

Sickles Ii, J. E. and Shadwick, D. S.: Precision of atmospheric dry deposition data from the Clean Air Status and Trends Network, Atmos. Environ., 36, 5671-5686, 2002.

Sinclair, A. and Tolsma, D.: Air pollution and acute cardiorespiratory visits in an ambulatory care setting: two year and preliminary four year results, Epidemiology, 15, p. 25, 2004.
Son, J. Y., Lee, J. T., Kim, K. H., Jung, K., and Bell, M. L.: Characterization of Fine Particulate Matter and Associations between Particulate Chemical Constituents and Mortality in Seoul, Korea, Environ. Health Persp., 120, 872-878, 2012.

Stieb, D. M., Chen, L., Eshoul, M., and Judek, S.: Ambient air pollution, birth weight and preterm birth: A systematic review and meta-analysis, Environ. Res., 117, 100-111, 2012.

Taback, H. J., Brienza, A. R., Macko, J., and Brunetz, N.: Fine particle emissions from stationary and miscellaneous sources in the South Coast Air Basin. Technical Report, Contract A6-191-30, California Air Resources Board, KVB Incorporate, ResearchCottrell, Tustin, California, 1979.

Tainio, M., Juda-Rezler, K., Reizer, M., Warchałowski, A., Trapp, W., and Skotak, K.: Future climate and adverse health effects caused by fine particulate matter air pollution: case study for Poland, Reg. Environ. Change, 13, 705-715, 2012.

Tesche, T. W., Morris, R., Tonnesen, G., McNally, D., Boylan, J., and Brewer, P.: CMAQ/CAMx annual 2002 performance evaluation over the eastern US, Atmos. Environ., 40, 4906-4919, 2006.

Tran, H. T., Alvarado, A., Garcia, C., Motallebi, N., Miyasato, L., and Vance, W.: Methodology for Estimating Premature Deaths Associated with Long-term Exposure to Fine Airborne Particulate Matter in California, Staff Report, California Environmental Protection Agency, Air Resources Board, 2008.

Turpin, B. J. and Lim, H. J.: Species contributions to $\mathrm{PM}_{2.5}$ mass concentrations: revisiting common assumptions for estimating organic mass, Aerosol Sci. Tech., 35, 602-610, 2010.

U.S.EPA: Guidance on the Use of Models and Other Analyses for Demonstrating Attainment of Air Quality Goals for Ozone, $\mathrm{PM}_{2.5}$ and Regional Haze, in: Agency,edited by: U.S.E.P., Research Triangle Park, North Carolina, 2007.

Vineis, P., Hoek, G., Krzyzanowski, M., Vigna-Taglianti, F., Veglia, F., Airoldi, L., Autrup, H., Dunning, A., Garte, S., Hainaut, P., Malaveille, C., Matullo, G., Overvad, K., Raaschou-Nielsen, O., Clavel-Chapelon, F., Linseisen, J., Boeing, H., Trichopoulou, A., Palli, D., Peluso, M., Krogh, V., Tumino, R., Panico, S., BuenoDe-Mesquita, H. B., Peeters, P. H., Lund, E. E., Gonzalez, C. A., Martinez, C., Dorronsoro, M., Barricarte, A., Cirera, L., Quiros, J. R., Berglund, G., Forsberg, B., Day, N. E., Key, T. J., Saracci, R., Kaaks, R., and Riboli, E.: Air pollution and risk of lung cancer in a prospective study in Europe, Int. J. Cancer., 119, 169174, 2006.

Volkamer, R., Jimenez, J. L., San Martini, F., Dzepina, K., Zhang, Q., Salcedo, D., Molina, L. T., Worsnop, D. R., and Molina, M. J.: Secondary organic aerosol formation from anthropogenic air pollution: Rapid and higher than expected, Geophys. Res. Lett., 33, L17811, doi:10.1029/2006GL026899, 2006.

Vukovich, J. M. and Pierce, T.: The Implementation of BEIS3 within the SMOKE modeling framework, MCNCEnvironmental Modeling Center, Research Triangle Park and National Oceanic and Atmospheric Administration, 2002.

Walker, J. M., Philip, S., Martin, R. V., and Seinfeld, J. H.: Simulation of nitrate, sulfate, and ammonium aerosols over the United States, Atmos. Chem. Phys., 12, 11213-11227, doi:10.5194/acp12-11213-2012, 2012.

Wang, K., Zhang, Y., Yahya, K., Wu, S.-Y., and Grell, G.: Implementation and Initial Application of New Chemistry-Aerosol Options in WRF/Chem for Simulating Secondary Organic Aerosols and Aerosol Indirect Effects for Regional Air Qual- 
ity, Atmos. Environ., available at: http://www.sciencedirect.com/ science/article/pii/S1352231014009558 (last access: 3 December 2014), doi:10.1016/j.atmosenv.2014.12.007, 2015.

Wei Wang, C. B., Duda, M., Dudhia, J., Gill, D., Lin, H.-C., Michalakes, J., Rizvi, S., and Zhang, X.: The Advanced Research WRF (ARW) Version 3 Modeling System User's Guide, 2010.

Wiedinmyer, C., Akagi, S. K., Yokelson, R. J., Emmons, L. K., AlSaadi, J. A., Orlando, J. J., and Soja, A. J.: The Fire INventory from NCAR (FINN): a high resolution global model to estimate the emissions from open burning, Geosci. Model Dev., 4, 625641, doi:10.5194/gmd-4-625-2011, 2011.

Willers, S. M., Eriksson, C., Gidhagen, L., Nilsson, M. E., Pershagen, G., and Bellander, T.: Fine and coarse particulate air pollution in relation to respiratory health in Sweden, Eur. Respir. J., 42, 924-934, 2013.

Skamarock, W., Klemp, J. B., Dudhia, J., O Gill, D., Barker, D., Duda, M. G., Huang, X.-Y., and Wang W.: A Description of the Advanced Research WRF Version 3, NCAR Technical Note NCAR/TN-475+STR, 2008.

WRAP: Fire Emission Inventory for the WRAP Region - Phase II, Air Sciences Inc., 2002, 2005

Ying, Q. and Kleeman, M. J.: Source contributions to the regional distribution of secondary particulate matter in California, Atmos. Environ., 40, 736-752, 2006.

Ying, Q., Fraser, M. P., Griffin, R. J., Chen, J. J., and Kleeman, M. J.: Verification of a source-oriented externally mixed air quality model during a severe photochemical smog episode, Atmos. Environ., 41, 1521-1538, 2007.
Ying, Q., Lu, J., Allen, P., Livingstone, P., Kaduwela, A., and Kleeman, M.: Modeling air quality during the California Regional $\mathrm{PM}_{10} / \mathrm{PM}_{2.5}$ Air Quality Study (CRPAQS) using the UCD/CIT source-oriented air quality model - Part I. Base case model results, Atmos. Environ., 42, 8954-8966, 2008.

Yu, S. C., Dennis, R., Roselle, S., Nenes, A., Walker, J., Eder, B., Schere, K., Swall, J., and Robarge, W.: An assessment of the ability of three-dimensional air quality models with current thermodynamic equilibrium models to predict aerosol $\mathrm{NO}_{3}-$, J. Geophys. Res.-Atmos., 110, D07S13, doi:10.1029/2004JD004718, 2005.

Zhang, H. L. and Ying, Q.: Source apportionment of airborne particulate matter in Southeast Texas using a source-oriented 3D air quality model, Atmos. Environ., 44, 3547-3557, 2010.

Zhang, H. and Ying, Q.: Secondary organic aerosol formation and source apportionment in Southeast Texas, Atmos. Environ., 45, 3217-3227, 2011.

Zhao, Z., Chen, S. H., Kleeman, M. J., Tyree, M., and Cayan, D.: The Impact of Climate Change on Air Quality-Related Meteorological Conditions in California. Part I: Present Time Simulation Analysis, J. Clim., 24, 3344-3361, 2011.

Zhang, H., Chen, G., Hu, J., Chen, S.-H., Wiedinmyer, C., Kleeman, M., and Ying, Q.: Evaluation of a seven-year air quality simulation using the Weather Research and Forecasting (WRF)/Community Multiscale Air Quality (CMAQ) models in the eastern United States, Sci. Total Environ., 473-474, 275-285, 2014a.

Zhang, H., DeNero, S. P., Joe, D. K., Lee, H.-H., Chen, S.-H., Michalakes, J., and Kleeman, M. J.: Development of a source oriented version of the WRF/Chem model and its application to the California regional $\mathrm{PM}_{10} / \mathrm{PM}_{2.5}$ air quality study, Atmos. Chem. Phys., 14, 485-503, doi:10.5194/acp-14-485-2014, 2014b. 